Louisiana State University

LSU Digital Commons

Faculty Publications

Department of Biological Sciences

$10-31-2017$

\title{
The Stringent Response Induced by Phosphate Limitation Promotes Purine Salvage in Agrobacterium fabrum
}

\author{
Smitha Sivapragasam \\ Louisiana State University \\ Dinesh K. Deochand \\ Louisiana State University \\ Jacob K. Meariman \\ Louisiana State University \\ Anne Grove \\ Louisiana State University
}

Follow this and additional works at: https://digitalcommons.Isu.edu/biosci_pubs

\section{Recommended Citation}

Sivapragasam, S., Deochand, D., Meariman, J., \& Grove, A. (2017). The Stringent Response Induced by Phosphate Limitation Promotes Purine Salvage in Agrobacterium fabrum. Biochemistry, 56 (43), 5831-5843. https://doi.org/10.1021/acs.biochem.7b00844

This Article is brought to you for free and open access by the Department of Biological Sciences at LSU Digital Commons. It has been accepted for inclusion in Faculty Publications by an authorized administrator of LSU Digital Commons. For more information, please contact ir@lsu.edu. 


\title{
The Stringent Response Induced by Phosphate Limitation Promotes Purine Salvage in Agrobacterium fabrum
}

\author{
Smitha Sivapragasam, ${ }^{\dagger}$ Dinesh K. Deochand, ${ }^{\ddagger}$ J Jacob K. Meariman, ${ }^{\S}$ and Anne Grove*(i) \\ Department of Biological Sciences, Louisiana State University, Baton Rouge, Louisiana 70803, United States
}

\begin{abstract}
Agrobacterium fabrum induces tumor growth in susceptible plant species. The upregulation of virulence genes that occurs when the bacterium senses plant-derived compounds is enhanced by acidic $\mathrm{pH}$ and limiting inorganic phosphate. Nutrient starvation may also trigger the stringent response, and purine salvage is among the pathways expected to be favored under such conditions. We show here that phosphate limitation induces the stringent response, as evidenced by production of (p)ppGpp, and that the $x d h C S M L$

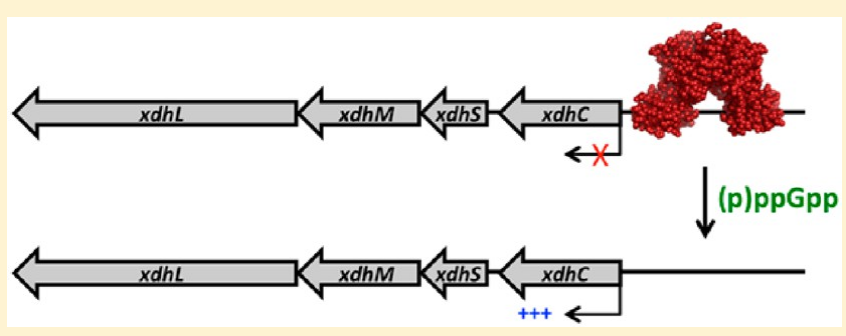
operon encoding the purine salvage enzyme xanthine dehydrogenase is upregulated $\sim 15$-fold. The $x d h C S M L$ operon is under control of the TetR family transcription factor XdhR; direct binding of ppGpp to XdhR attenuates DNA binding, and the enhanced $x d h C S M L$ expression correlates with increased cellular levels of (p)ppGpp. Xanthine dehydrogenase may also divert purines away from salvage pathways to form urate, the ligand for the transcription factor PecS, which in the plant pathogen Dickeya dadantii is a key regulator of virulence gene expression. However, urate levels remain low under conditions that produce increased levels of $x d h C S M L$ expression, and neither acidic $\mathrm{pH}$ nor limiting phosphate results in induction of genes under control of PecS. Instead, expression of such genes is induced only by externally supplemented urate. Taken together, our data indicate that purine salvage is favored during the stringent response induced by phosphate starvation, suggesting that control of this pathway may constitute a novel approach to modulating virulence. Because bacterial purine catabolism appears to be unaffected, as evidenced by the absence of urate accumulation, we further propose that the PecS regulon is induced by only host-derived urate.
\end{abstract}

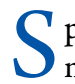
pecies in the Gram-negative genus Agrobacterium are members of the class $\alpha$-proteobacteria that also includes several nitrogen-fixing symbionts of leguminous plants. Agrobacterium fabrum (formerly classified as Agrobacterium tumefaciens) causes crown gall disease in various economically important plants. Although A. fabrum has been studied for decades, its pathogenicity remains uncontrolled and it is still considered to be one of the most significant plant pathogens. ${ }^{1}$

A. fabrum initiates tumor growth via the transfer of a large segment of the tumor-inducing Ti plasmid (the T-DNA) into the plant genome such that the transformed host cell expresses T-DNA genes. The bacterium can also sense plant-derived signals or other environmental conditions to ensure expression of Ti-encoded or chromosomally encoded virulence genes only upon host infection. ${ }^{2,3}$ Acidic $\mathrm{pH}(\sim 5.5$, the $\mathrm{pH}$ of the rhizosphere and the site of infection) and limiting inorganic phosphate are among the environmental conditions that contribute to virulence (vir) gene expression. ${ }^{4-6}$

Unfavorable conditions can also trigger the stringent response, which depends on production of $5^{\prime}$-triphosphate- $3^{\prime}$ diphosphate (pppGpp) and $5^{\prime}$-diphosphate-3'-diphosphate (ppGpp), together termed ( $\mathrm{p}$ )ppGpp. Production of (p)ppGpp has been mainly characterized in Escherichia coli, where it is produced by the paralogous enzymes RelA and SpoT. ${ }^{7,8}$ Less is known about (p)ppGpp synthesis and its regulatory roles in $\alpha$-proteobacteria, which appear to encode a single dual-function Rsh (RelA/SpoT homology) enzyme that can both synthesize and degrade (p)ppGpp. ${ }^{9}$ In Sinorhizobium meliloti, a nitrogen-fixing $\alpha$-proteobacterium that forms root nodules on leguminous plants, (p)ppGpp has been shown to play global roles in transcription and to be required for the formation of root nodules; ${ }^{10,11}$ induction of ( $\mathrm{p}$ )ppGpp is most effectively induced by starvation for carbon or nitrogen and not by starvation for a few amino acids. ${ }^{12,13}$

In general, ( $\mathrm{p}$ )ppGpp functions to promote expression of genes required for survival and virulence while downregulating processes associated with rapid growth. The mechanistic roles of (p)ppGpp are complex and different in Gram-positive and Gram-negative species. In Gram-positive bacteria, a primary function is to control cellular levels of GTP by regulating enzymes involved in the biosynthesis of guanosine nucleotides, while direct binding of ( $\mathrm{p}$ )ppGpp to RNA polymerase is key to the stringent response in Gram-negative species such as $E$. coli. ${ }^{7,8,14-16}$ In $S$. meliloti, suppressors of the (p)ppGpp ${ }^{0}$ phenotype map to $r p o B$ and $r p o C$, which encode the $\beta$ and $\beta^{\prime}$ subunits of RNA polymerase, also suggesting direct interaction with RNA polymerase. ${ }^{11}$

The stringent response is designed to allow more efficient utilization of scarce resources; hence, upregulation of purine salvage is part of this metabolic response because it promotes a

Received: August 28, 2017

Revised: October 11, 2017

Published: October 13, 2017 

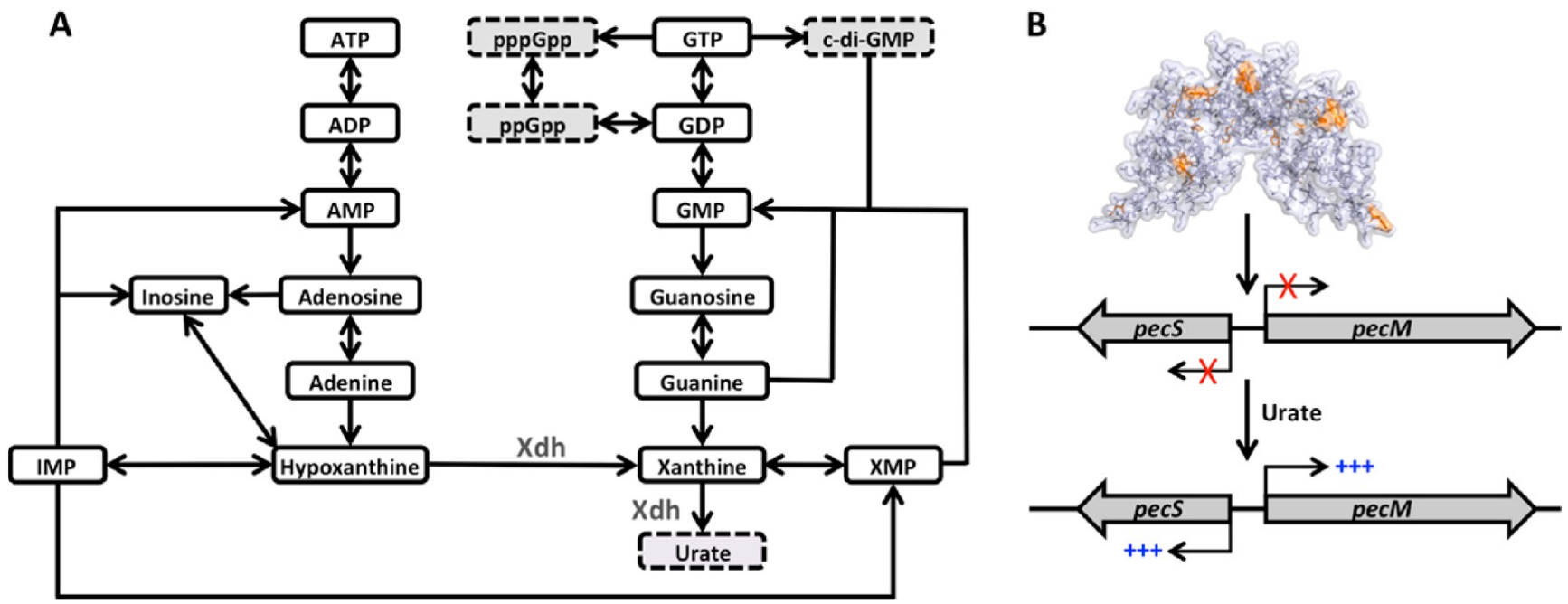

Figure 1. Urate, produced by Xdh, is a ligand for PecS. (A) Outline of the purine salvage pathway in A. fabrum. Xdh-catalyzed steps, conversion of hypoxanthine to xanthine and xanthine to urate, are identified, along with the production of ppGpp, pppGpp, and c-di-GMP from GDP and GTP; pathways are represented on the basis of the KEGG pathway database (http://www.genome.jp/kegg/pathway/map/map00230.html). (B) Dimeric A. fabrum PecS with His residues colored orange (eight His residues per monomer). Binding of PecS to the pecS-pecM intergenic region represses both genes. Binding of urate to PecS attenuates DNA binding and leads to gene expression.

recycling of purines that are released during cellular metabolism. The enzyme xanthine dehydrogenase (Xdh) participates by converting hypoxanthine to xanthine [thereby favoring synthesis of guanosine nucleotides (Figure 1A)], as exemplified by a mutant of $E$. coli $x d h$, which is impaired in converting adenine to guanine. ${ }^{17}$ Consistent with a role for purine salvage in the stringent response, the level of expression of $S$. meliloti genes encoding $\mathrm{Xdh}$ is increased upon carbon or nitrogen starvation, conditions that lead to accumulation of (p)ppGpp. ${ }^{13}$ Similarly, in the Gram-positive Streptomyces coelicolor, the operon encoding $\mathrm{Xdh}$ is upregulated during the stationary phase when (p)ppGpp levels are highest. ${ }^{18,19}$

$\mathrm{Xdh}$ can also divert purines away from salvage pathways by catalyzing the oxidation of xanthine to urate (Figure 1A). ${ }^{20,21}$ In plants, such production of urate (which is an antioxidant) has been observed during the pathogen defense response to protect plant cells from oxidative damage. ${ }^{22}$ This is relevant because $A$. fabrum encodes the urate-responsive MarR family transcription factor PecS (Figure 1B). ${ }^{23,24}$ In the plant pathogen Dickeya dadantii, PecS has been shown to be a key regulator of virulence gene expression; however, signals that induce the $D$. dadantii PecS regulon remain unknown. ${ }^{25,26}$ In the related pathogen Pectobacterium atrosepticum, PecS responds to urate and to changes in $\mathrm{pH}^{27}$ It is unknown, however, whether upregulation of bacterial Xdh is also linked to an increased level of accumulation of urate and thereby production of the PecS ligand in this species.

Increased production of Xdh has been previously associated with the stringent response in other bacterial species. We therefore investigated if $x d h$ is likewise induced during the stringent response in A. fabrum, which would suggest a role in virulence. We specifically addressed if the stringent response would lead to increased purine salvage or if it would result in enhanced purine catabolism and therefore cause urate production and an increased level of expression of genes under PecS control. We show here that the stringent response induced by phosphate limitation leads to upregulation of the $x d h$ operon and that this is associated with increased purine salvage [(p)ppGpp synthesis], but not purine catabolism (urate accumulation). Because the stringent response does not lead to accumulation of urate, we infer that it is plant-derived urate that functions as a PecS ligand.

\section{MATERIALS AND METHODS}

Identifying the $x d h C S M L$ Start Site. A stationary phase (approximately $120 \mathrm{~h}$ ) culture of A. fabrum GV3101 (a disarmed derivative of C58) was pelleted and stored at $-80{ }^{\circ} \mathrm{C}$. The pellet was washed with diethyl pyrocarbonate (DEPC)treated water, and RNA was isolated using the illustra RNAspin Mini kit (GE Healthcare). The isolated RNA was treated with TURBO DNase (Ambion/Life Technologies) using the manufacturer's protocol. Approximately $10 \mu \mathrm{g}$ of RNA was treated with tobacco acid pyrophosphatase and then ligated to an adapter provided in the FirstChoice RLM-RACE kit (Ambion). The ligated RNA was then converted to cDNA using random primers according to the manufacturer's protocol. Polymerase chain reactions (PCRs) were performed using the primers supplied by the manufacturer and gene specific primers. The product generated was analyzed using agarose gel electrophoresis, followed by staining with ethidium bromide. PCR products were extracted from gel slices using Wizard Gel and PCR Clean-Up (Promega) and sequenced.

Protein Preparation. The Atu5496 ( $x d h R$ ) gene from A. fabrum GV3101 was amplified from genomic DNA using primers 5'-AGCTATCATATGACTTGCGATC-3' and 5'CAGCTTAAGCTTCTAACGCCGTAG-3' (restriction sites underlined). The PCR product was cloned into pET28b between NdeI and XhoI sites, and the resultant plasmid was transformed into E. coli TOP10 cells. The plasmid was sequenced to confirm the integrity of the clone and transformed into E. coli BL21(DE3) for overexpression of protein with an $\mathrm{N}$-terminal $\mathrm{His}_{6}$ tag. Cells were grown in LB medium containing $30 \mu \mathrm{g} \mathrm{mL} \mathrm{m}^{-1}$ kanamycin, and $\mathrm{XdhR}$ expression was induced with $1 \mathrm{mM}$ isopropyl $\beta$-D-1thiogalactopyranoside (IPTG). Six hours after induction, cells were pelleted and stored at $-80{ }^{\circ} \mathrm{C}$. Cells were resuspended in lysis buffer [20 mM sodium phosphate ( $\mathrm{pH} 8.0), 150 \mathrm{mM}$ $\mathrm{NaCl}, 5 \%$ glycerol, $0.15 \mathrm{mM}$ phenylmethanesulfonyl fluoride 
(PMSF), and $10 \mathrm{mM} \beta$-mercaptoethanol], and lysozyme was added to a final concentration of $200 \mu \mathrm{g} \mathrm{mL}^{-1}$. The cells were disrupted by sonication on ice. The lysed cells were centrifuged at $15000 \mathrm{rpm}$ for $1 \mathrm{~h}$, and the lysate was incubated with $1 \mathrm{~mL}$ of HIS Select Nickel affinity gel for $30 \mathrm{~min}$. The $\mathrm{His}_{6}$-tagged protein was eluted according to the manufacturer's instructions (Sigma). Buffer exchange into storage buffer [20 mM sodium phosphate ( $\mathrm{pH} 8.0$ ), $150 \mathrm{mM} \mathrm{NaCl}, 20 \%$ glycerol, $0.15 \mathrm{mM}$ PMSF, and $10 \mathrm{mM} \beta$-mercaptoethanol], and the sample was concentrated using $10 \mathrm{~K}$ centrifugal filter units (Millipore). The purified XdhR concentration was estimated using the MicroBCA protein assay kit. A. fabrum PecS was prepared and characterized as described previously. ${ }^{28}$

Thermal Stability Assay (TSA). PecS was diluted in TSA buffer [50 mM Tris- $\mathrm{HCl}(\mathrm{pH} 8.0)$, Hepes ( $\mathrm{pH} 7.0)$, 2-(Nmorpholino)ethanesulfonic acid (MES) ( $\mathrm{pH}$ 6.0), or acetate (pH 5.0), each with $100 \mathrm{mM} \mathrm{NaCl}$ and 5× SYPRO Orange dye (Invitrogen)]. Fluorescence emission induced by binding of SYPRO Orange dye was monitored over a temperature range of 5-90 ${ }^{\circ} \mathrm{C}$ in $1{ }^{\circ} \mathrm{C}$ increments on an Applied Biosystems 7500 Real Time PCR instrument. The SYBR Green filter was used for fluorescence intensity measurement. ${ }^{29}$ The data were analyzed using Sigma Plot 9, using the four-parameter sigmoidal equation. The $T_{\mathrm{m}}$ values reported are the average [ \pm standard deviation (SD)] of three replicates. As discussed previously, the temperature coefficients for Tris, Hepes, and MES will result in a decreased $\mathrm{pH}$ with an increase in temperature, whereas the temperature coefficient for acetate is negligible. $^{30}$

Size Exclusion Chromatography. A Superose column (GE Healthcare) was pre-equilibrated with buffer at $\mathrm{pH} 8.0$ (50 $\mathrm{mM}$ Tris and $150 \mathrm{mM} \mathrm{NaCl}$ ). The protein sample was diluted in the same buffer and loaded on the column using a fast protein liquid chromatography (FPLC) system. Bio-Rad size exclusion standards bovine $\gamma$-globulin $(158.0 \mathrm{kDa})$, ovalbumin $(44.0 \mathrm{kDa})$, myoglobin $(17.0 \mathrm{kDa})$, and vitamin $\mathrm{B}_{12}(1.35 \mathrm{kDa})$ were run on the same column, and a standard curve was plotted using the respective elution volumes obtained for each standard. The formula $K_{\mathrm{av}}=\left(V_{\mathrm{E}}-V_{\mathrm{O}}\right) /\left(V_{\mathrm{T}}-V_{\mathrm{O}}\right)$ was used to calculate the average molecular weight of the protein, where $V_{\mathrm{E}}$ is the retention volume of the protein, $V_{\mathrm{O}}$ is the void volume of the column, and $V_{\mathrm{T}}$ is the bed volume of the column. ${ }^{29}$

Electrophoretic Mobility Shift Assays (EMSAs). A PCR product of $214 \mathrm{bp}$ containing the intergenic region between the $x d h$ gene cluster and the $x d h R$ gene was amplified using primers Agrointergenic-FP 5'-GAAGGGCACTCCATGAGAAA-3' and Agrointergenic-RP 5'-CTCCCGTGTGAGGTCAGAAT-3'. T4 polynucleotide kinase was used to label the PCR product with $\left[\gamma_{-}{ }^{32} \mathrm{P}\right] \mathrm{ATP} . \mathrm{XdhR}$ was titrated into the labeled DNA in binding buffer [25 mM Tris ( $\mathrm{pH} 8.0), 100 \mathrm{mM} \mathrm{NaCl}, 1 \mathrm{mM}$ EDTA, $0.05 \%$ Brij58, $5 \mathrm{mM} \mathrm{DTT}$, and $2 \%$ glycerol] and incubated at room temperature for $20 \mathrm{~min}$. Polyacrylamide gels [8\%; 39:1 $(\mathrm{w} / \mathrm{w})$ acrylamide:bisacrylamide] were prerun for $30 \mathrm{~min}$ at room temperature in $0.5 \times \mathrm{TBE}(45 \mathrm{mM}$ Tris-borate and $1 \mathrm{mM}$ EDTA) running buffer. The samples were loaded onto the gels and run for $1 \mathrm{~h}$ at $100 \mathrm{~V}$. The gels were dried and exposed to phosphor screens. A Storm 840 scanner (GE Healthcare) was used to scan the image, and the bands were quantified using ImageQuant version 5.1. The regions on the gels between the complex and free DNA were considered as complex. KaleidaGraph software was used to create the plots, and the data were fitted to a single-site binding isotherm $f=f_{\max }[\mathrm{X}] /\left(K_{\mathrm{d}}+[\mathrm{X}]\right)$, where $f$ is the fractional saturation (complex relative to total
DNA), $K_{d}$ is the equilibrium dissociation constant, and $[\mathrm{X}]$ is the protein concentration. Data are reported as means $\pm \mathrm{SD}$ from three replicates. To assess the specificity of XdhR, EMSAs in which nonspecific plasmid DNA (pRAD1, $6.3 \mathrm{~kb}$ ) or specific unlabeled DNA was titrated against labeled DNA in the binding buffer described above were performed.

The ligands xanthine, hypoxanthine, adenine, guanosine, and urate were used in EMSAs to analyze their effect on DNA$\mathrm{XdhR}$ binding as were the phosphorylated guanosine derivatives ppGpp (TriLink), c-di-GMP, GTP, and GMP. $\mathrm{NaOH}(0.4 \mathrm{~N})$ was used to dissolve the former set of ligands, and $500 \mathrm{mM}$ Tris ( $\mathrm{pH} \mathrm{8.0)}$ was used in the binding buffer to prevent changes in $\mathrm{pH}$ upon addition of these ligands. The phosphorylated guanosine derivatives were included using the binding buffer described above [containing $25 \mathrm{mM}$ Tris $(\mathrm{pH}$ 8.0)]. To a mixture containing DNA and ligand in the appropriate binding buffer was added $\mathrm{XdhR}$, and the mixture was incubated for $20 \mathrm{~min}$. Once the samples were loaded, the gel was run for $1 \mathrm{~h}$ at $100 \mathrm{~V}$. $\mathrm{IC}_{50}$ was calculated as the concentration of the ligand at which $50 \%$ of complex formation is inhibited using the equation $f=A+B \mathrm{e}^{-k L}$, where $f$ is fractional saturation, $k$ is the decay constant, $L$ is the ligand concentration, $A$ is the saturation plateau, and $B$ is the decay amplitude. Inhibition constants $\left(K_{\mathrm{i}}\right)$ were calculated from the equation $K_{\mathrm{i}}=\mathrm{IC}_{50} /\left([\mathrm{DNA}]_{50} / K_{\mathrm{d}}+[\mathrm{XdhR}]_{0} / K_{\mathrm{d}}+1\right)$, where $[\mathrm{DNA}]_{50}$ is the concentration of DNA at $50 \%$ inhibition and $[\mathrm{XdhR}]_{0}$ is the protein concentration at $0 \%$ inhibition. ${ }^{31} K_{\mathrm{i}}$ is reported as the mean $\pm S D$ from three replicates.

DNasel Footprinting. A $391 \mathrm{bp}$ PCR product containing the intergenic region between $x d h$ and $x d h R$ was amplified using primers AgroFP 5'-(6-FAM)-ATGCCAGCGACGCAACTTCTATCAAC-3' and AgroRP 5'-GTCGGCATTGCGAGGCAACC-3', where 6-FAM reflects 5'-end labeling with 6carboxyfluorescein. The labeled DNA (50 ng) was incubated with varying concentrations of $\mathrm{XdhR}$ for $10 \mathrm{~min}$ at room temperature in EMSA binding buffer, followed by addition of $1 \times$ DNaseI reaction buffer (New England BioLabs). The DNaseI digestion reaction was performed with 0.08 unit of enzyme and $50 \mathrm{ng}$ of labeled DNA and the mixture incubated at room temperature for $3.5 \mathrm{~min}$. The reaction was stopped using $8 \mathrm{mM} \mathrm{Na}{ }_{2}$ EDTA. The digested DNA was then extracted twice using phenol:chloroform and precipitated with ethanol. The DNA pellet was washed with $70 \%$ ethanol and the DNA dissolved in $10 \mu \mathrm{L}$ of $\mathrm{Hi}-\mathrm{Di}$ formamide. Footprinting of PecS was performed similarly, using 337 bp pecS-pecM intergenic DNA amplified with primers PecSF 5'-(6-FAM)-GGGCCGACATCGAGATCGGGTCGTT-3' and PecSR 5'-AGCTTTCGGACGAGAAGCAGCAGCAGGAT-3'.

An aliquot of $0.05 \mathrm{ng}$ of undigested DNA (to maintain a fluorescence intensity that is compatible with the analyzer) and $0.2 \mathrm{ng}$ of digested DNA was used for fragment analysis. ${ }^{32} \mathrm{An}$ ABI 3130 analyzer with default settings of a $1.6 \mathrm{kV}$ injection voltage and a $15 \mathrm{~s}$ injection time was used for fragment analysis. The LIZ 500 ladder (ABI-Life Technologies) was diluted 1:10 and added to each sample before being loaded on to the analyzer. GeneMapper version 4 was used to analyze the data. Electropherogram traces of digested $x d h-x d h R$ DNA were overlaid with those of the digested DNA that was incubated with XdhR. A Thermo Sequenase PCR cycle sequencing reaction was performed using the same 6-FAM-labeled primer and all four dideoxynucleotides in separate tubes. The products generated from these reactions were analyzed using fragment analysis and overlaid with that of the digested fragments to 


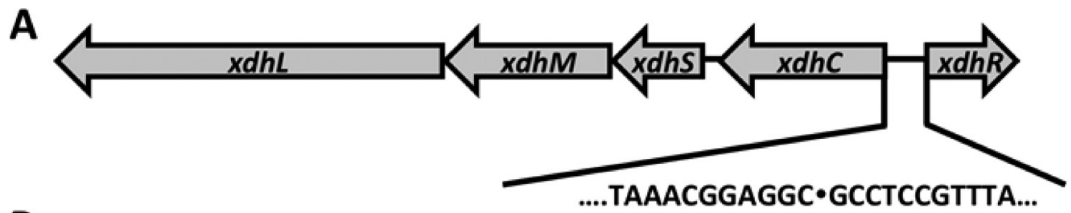

B 12
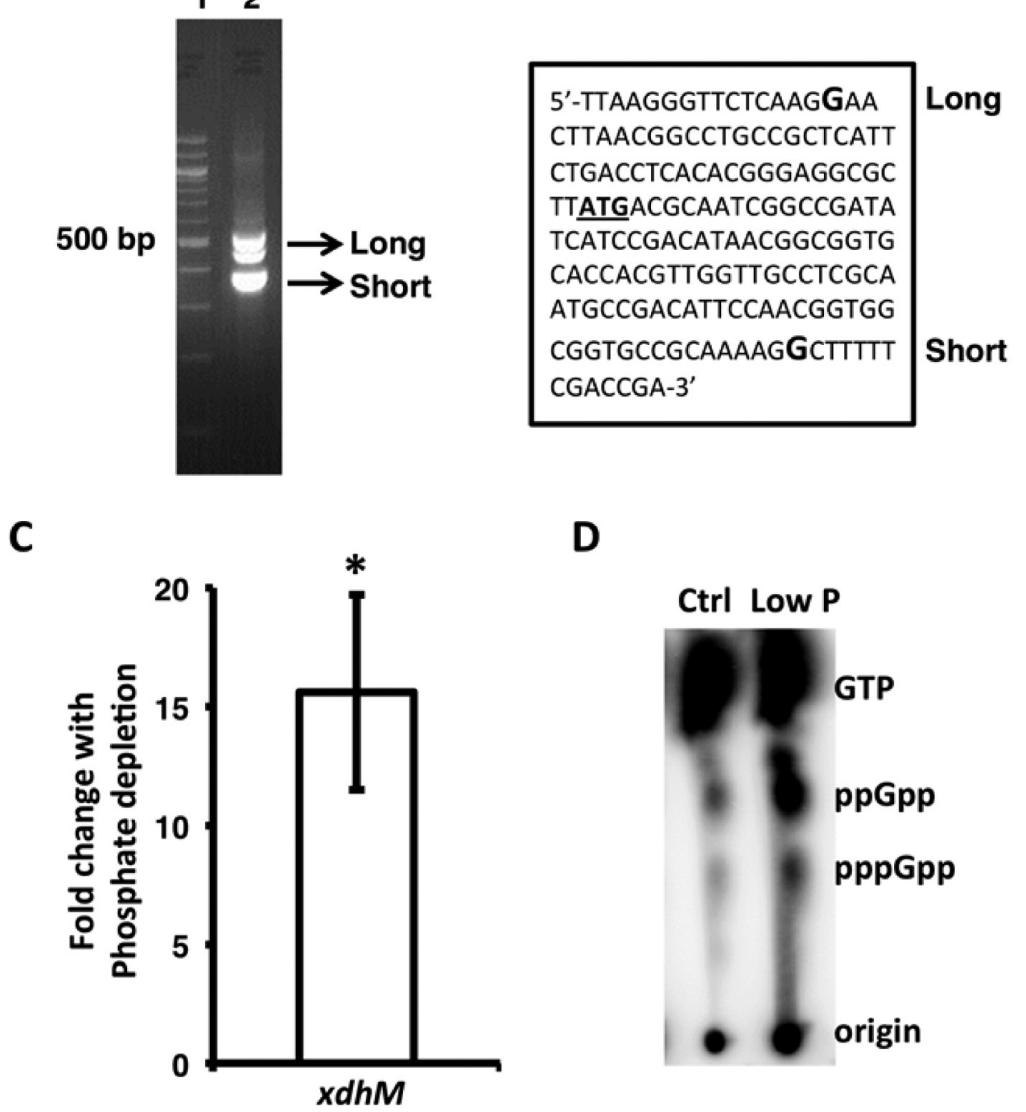

D

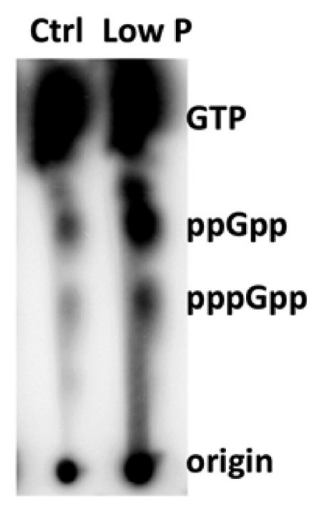

Figure 2. Locus encoding Xdh and gene expression during phosphate starvation. (A) Divergent orientation of $x d h C S M L$ and $x d h R$ genes. The palindrome found in the intergenic region is identified at the bottom. (B) Mapping of the $x d h C S M L$ transcriptional start. Agarose gel showing PCR products obtained after 5'-RACE. Lane 1 shows the size marker. The sequence of the coding strand is shown beside the gel. Bolded Gs correspond to the identified transcriptional start sites of Long and Short products; the underlined ATG is the annotated translational start. The middle product was not sequenced. (C) $x d h M$ transcript level determined by qRT-PCR after phosphate starvation for $24 \mathrm{~h}$ relative to cells grown with ample phosphate (mean \pm standard deviation from two independent experiments; $*_{p}<0.05$ ). (D) Thin layer chromatography of nucleotides extracted from A. fabrum grown with ample phosphate (control) or after phosphate starvation for $24 \mathrm{~h}$ (representative of three independent experiments).

identify the sequence protected by XdhR. Electropherogram traces of digested pecS-pecM DNA were overlaid with those of the digested DNA that was incubated with PecS, and protected DNA sites were identified by comparison to previously reported footprints mapped using Maxam-Gilbert sequencing. ${ }^{28}$ Footprints are representative of at least three replicates.

Reverse Transcriptase PCR. A. fabrum was grown in $2 \times$ LB medium for 24-36 $\mathrm{h}$ and then subcultured. For analysis of gene expression after $\mathrm{Xdh}$ inhibition, cells were subcultured in $2 \times \mathrm{LB}$ until the $\mathrm{OD}_{600}$ reached $\sim 0.2$ and then treated with 10 $\mathrm{mM}$ allopurinol or separately with a combination of $10 \mathrm{mM}$ allopurinol and either $10 \mathrm{mM}$ GMP or $10 \mathrm{mM}$ xanthine for the indicated times. The control cells were treated with an equal volume of $0.4 \mathrm{~N} \mathrm{NaOH}$, the solvent used to dissolve these ligands. For analysis of gene expression under phosphate limitation, cells were grown to stationary phase in $2 \times \mathrm{LB}$, washed three times in modified minimal medium $(\mathrm{pH} 7.0)$ containing $50 \mu \mathrm{g} \mathrm{mL}^{-1}$ phosphate (P50) or $2000 \mu \mathrm{g} \mathrm{mL}$ phosphate (P2000), resuspended in P50 or P2000 at an $\mathrm{OD}_{600}$ of $\sim 0.15$, and grown for $24 \mathrm{~h}$. To remove excess exopolysaccharide that accumulated after growth under phosphate limitation, cells were washed with $0.4 \mathrm{M} \mathrm{NaOH}$ followed by a wash with $50 \mathrm{mM}$ MES ( $\mathrm{pH}$ 5.5). For analysis of gene expression as a function of $\mathrm{pH}, \mathrm{A}$. fabrum was subcultured in phosphate-sufficient modified minimal medium buffered with MOPS ( $\mathrm{pH} 7.0$ ) or MES ( $\mathrm{pH} 5.5$ ).

RNA was extracted using acid phenol:chloroform, incubated with DNaseI, and then purified using the illustra RNAspin Mini kit (GE Healthcare) according to the manufacturer's protocol. Two micrograms of RNA was used for cDNA preparation using AMV reverse transcriptase (New England BioLabs). Quantitative PCR was performed on an Applied Biosystems 7500 RealTime PCR machine using SYBR Green I dye. Expression of the rim gene was used to normalize $x d h M$, pecS, and pecM gene expression. The expression level of the $x d h M$ gene was analyzed using primers xdhFP 5'-CCGAACTCGATACGGATGAT-3' and xdhRP 5'-AAACGAGAGCGAAGGCATAA-3', pecS transcripts with qpecSFwd 5'-CAGCGTCTTGATATCGCTGA-3' 
A

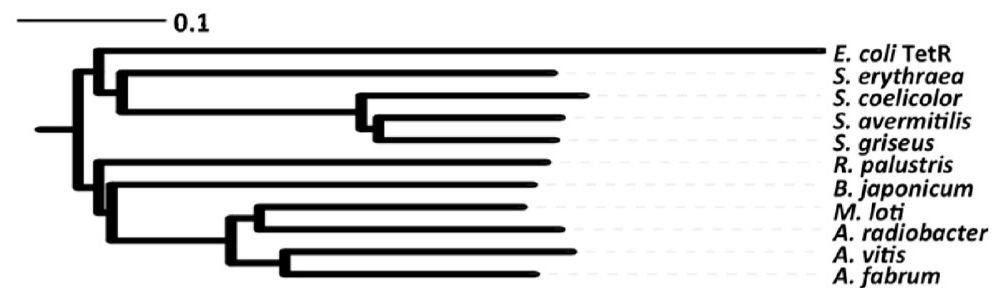

B

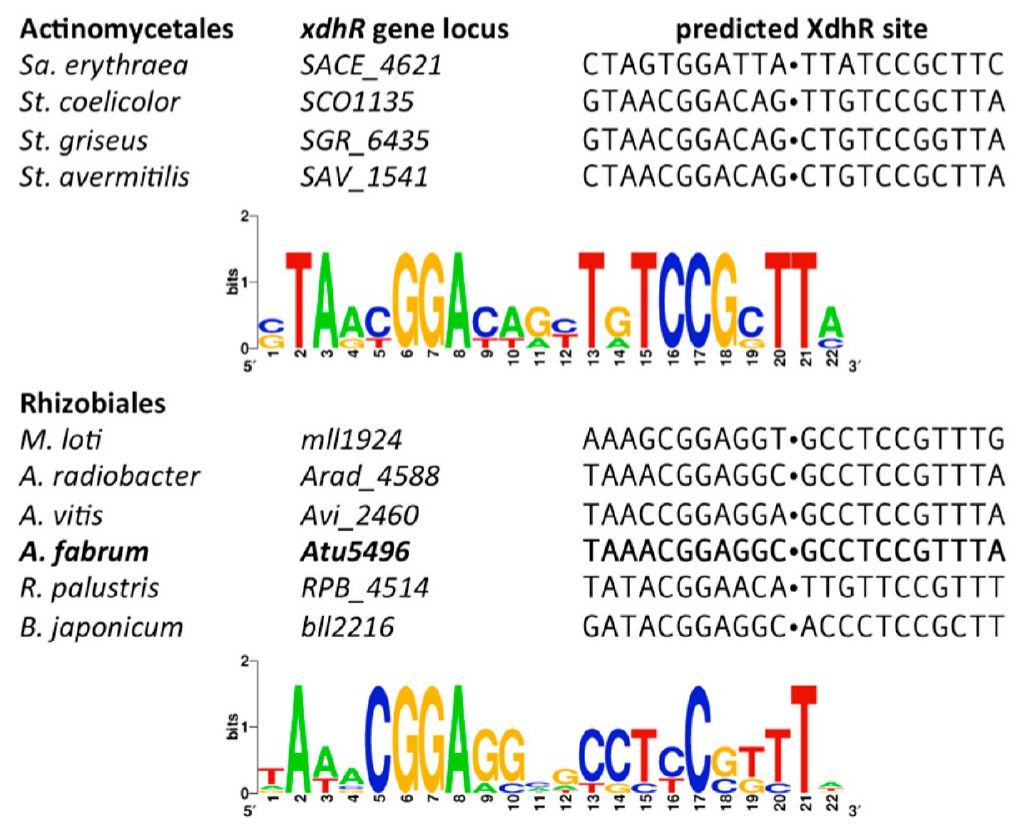

Figure 3. Conservation of XdhR. (A) XdhR from Actinomycetales and XdhR from Rhizobiales form separate clusters. Alignment of XdhR sequences was performed using using MUSCLE, and the neighbor-joining tree was created in iTOL. (B) Conserved palindromes in $x d h R$ promoters, representing predicted XdhR sites. Consensus sites created with WebLogo.

and qpecSRev 5'-CTCGAAGTCCTGCAGAAACC-3', pecM transcripts with qpecMFwd 5'-ACCTCACCTTCACAGCTTGG-3' and qpecMRev 5'-CCCACGAAACCACAGAAGAT- $3^{\prime}$, and rim gene transcripts with rimFP 5'-ACCCGATACTCATGGCAAAG-3' and RimRP 5'-ACGACGACATTCTTGCCTTC-3'. Data analysis was performed using the comparative threshold cycle method $\left(2^{-\Delta \Delta C T}\right)$. The results were obtained from two biological replicates, with each value derived from three technical replicates. For comparison of gene expression as a function of $\mathrm{pH}$ (where expression of the rim reference gene was $\mathrm{pH}$-dependent), PCR products representing two biological replicates were visualized by gel electrophoresis followed by staining with ethidium bromide.

Determination of Urate Levels. Stationary phase cells of A. fabrum were washed three times with P50 or P2000 and inoculated in the corresponding medium at an $\mathrm{OD}_{600}$ of $\sim 0.1$. The cells were incubated at $28{ }^{\circ} \mathrm{C}$ in a shaking incubator for 24 h. The cells were pelleted and washed with the reaction buffer from the Amplex Red Uric Acid Assay Kit (Thermo Fisher Scientific). Cells were suspended in the reaction buffer and lysed by sonication. The lysate was clarified by centrifugation, and the supernatant was used to estimate the urate content. The total protein was estimated using the BCA kit (Thermo Fisher). The levels of urate were normalized using the total protein concentration. The results obtained are the means \pm $\mathrm{SD}$ from three independent experiments.
(p)ppGpp Determination. For (p)ppGpp detection in $A$. fabrum, cells were grown for $36-48 \mathrm{~h}$ in $2 \times \mathrm{LB}$ medium and subcultured in phosphate-sufficient (P2000) or phosphatelimiting (P50) medium with $150 \mu \mathrm{Ci} / \mathrm{mL}$ of carrier-free ${ }^{32} \mathrm{P}$ labeled orthophosphate; $50 \mu \mathrm{L}$ of the culture was harvested at the indicated times and mixed with an equal volume of $13 \mathrm{M}$ formic acid. The samples were frozen and thawed three or four times, incubated on ice for $15 \mathrm{~min}$, and centrifuged for $10 \mathrm{~min}$ at $12000 \mathrm{~g}$ before $3 \mu \mathrm{L}$ of the sample was spotted on a PEIcellulose thin layer chromatography (TLC) plate (SigmaAldrich). The plates were developed in $1.5 \mathrm{M} \mathrm{KH}_{2} \mathrm{PO}_{4}(\mathrm{pH}$ 3.4) for $2 h^{33}$ Migration of GTP, GMP, and ATP was verified by spotting these purified nucleotides, and spots corresponding to ppGpp and pppGpp were identified on the basis of published Rf values using this buffer system. ${ }^{34}$ The plates were dried and exposed to phosphor screens. The images were scanned using a Storm 840 scanner (GE Healthcare). Images are representative of at least three replicates.

\section{RESULTS}

Induction of the $x d h C S M L$ Operon during the Stringent Response. As noted above, induction of genes encoding $\mathrm{Xdh}$ would be expected during the stringent response. A. fabrum encodes a predicted heterohexameric $(\alpha \beta \gamma)_{2} \mathrm{Xdh}$ (Atu5497-5500), with the upstream open reading frame Atu5497 predicted to encode the chaperone $\mathrm{XdhC}$. XdhC is required for $\mathrm{Xdh}$ assembly and for insertion of the 


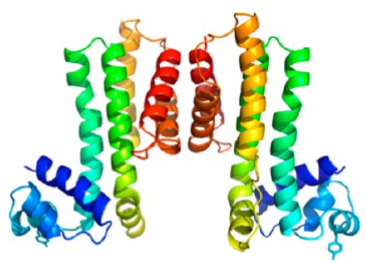

B

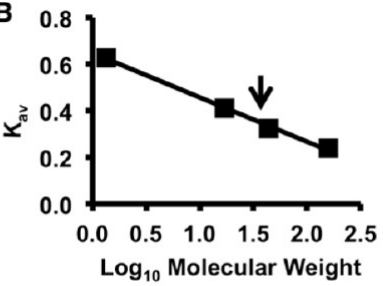

C

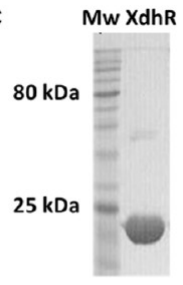

D

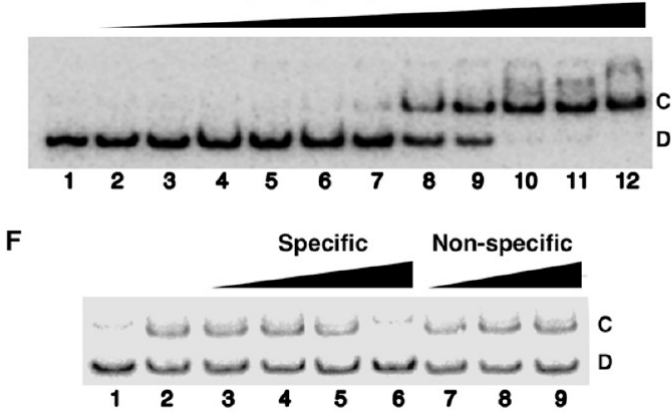

E

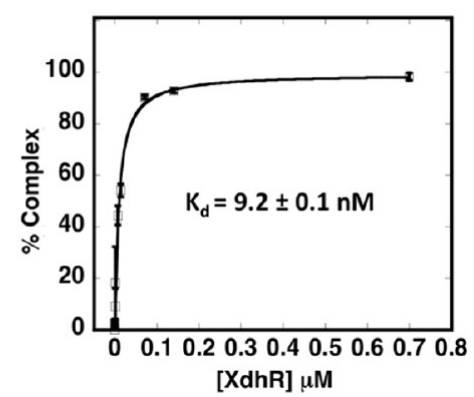

Figure 4. XdhR binds specifically to the $x d h C S M L-x d h R$ intergenic region. (A) Structure-based model created using SwissModel in automated mode using PDB entry 2Q24 as a template. The $\mathrm{N}$-terminal helices are colored blue and the C-terminal helices red. Tyrosine residues in DNA recognition helices (turquoise) are shown as sticks. (B) Graph showing the molecular weight of XdhR indicated by the arrow, determined by size exclusion chromatography. The $X$-axis represents $\log _{10}$ molecular weight, and the $Y$-axis represents $K_{\mathrm{av}}$ of Bio-Rad molecular weight standards. (C) Sodium dodecyl sulfate-polyacrylamide gel electrophoresis gel showing purified His ${ }_{6}$-tagged XdhR stained with Coomassie Brilliant Blue. (D) Electrophoretic mobility shift assay showing complex formation with increasing XdhR concentrations from lanes 2 to 12 (1.4 pM, $14 \mathrm{pM}, 70 \mathrm{pM}$, $0.14 \mathrm{nM}, 0.7 \mathrm{nM}, 1.4 \mathrm{nM}, 7 \mathrm{nM}, 14 \mathrm{nM}, 70 \mathrm{nM}, 140 \mathrm{nM}$, and $700 \mathrm{nM}$, respectively; $50 \mathrm{pM}$ DNA). Free DNA (D) and complex (C) identified at the right. (E) Percent XdhR-DNA complex formation as a function of XdhR concentration. (F) EMSA showing the specificity of binding (50 pM DNA): lane 1, DNA only; lanes 2-9, with $15 \mathrm{nM} \mathrm{XdhR;} \mathrm{lanes} \mathrm{3-6,} \mathrm{specific} \mathrm{unlabeled} \mathrm{DNA} \mathrm{(214} \mathrm{bp)} \mathrm{at} \mathrm{final} \mathrm{concentrations} \mathrm{of} \mathrm{0.05,} \mathrm{0.1,} \mathrm{0.5,} \mathrm{and} \mathrm{10}$ $\mathrm{nM}$, respectively; lanes 7-9, nonspecific plasmid DNA (pRAD1, $6.3 \mathrm{~kb}$ ) at final concentrations of $0.1,3.0$, and $7.0 \mathrm{nM}$, respectively.

molybdenum cofactor that is required for catalytic activity; $\mathrm{XdhC}$ does not become part of the active Xdh holoenzyme. ${ }^{35}$ Atu5497-5500 is encoded on the At plasmid, which has been proposed to confer an adaptive advantage on A. fabrum for its colonization of plant cells. ${ }^{36}$ Atu5498-5500 is homologous to the $x d h$ operon in St. coelicolor where it was designated $x d h A B C$; a fourth open reading frame in this operon is predicted to encode the $\mathrm{XdhC}$ chaperone. ${ }^{18}$ To avoid confusing nomenclature, we therefore designate Atu5497 as $x d h C$ and Atu5498-5500 as $x d h S M L$ in accord with other members of the xanthine oxidoreductase superfamily, ${ }^{35}$ with the small XdhS subunit predicted to contain the iron-sulfur cofactor, the medium XdhM harboring $\mathrm{FAD}$, and the large $\mathrm{XdhL}$ containing the molybdenum cofactor (Figure 2A). This operon is encoded divergently from a gene encoding the TetR family transcription factor XdhR, which is also conserved in St. coelicolor. ${ }^{18,19}$

Searching the STRING database (http://string-db.org/), which queries the genomic and functional context of target genes, ${ }^{37}$ revealed conservation of an operon encoding heterohexameric $\mathrm{Xdh}$ divergent from the $x d h R$ gene in a limited set of evolutionarily distant bacterial species. The occurrence of these genes was identified in Actinomycetales, specifically in Streptomyces spp. and in Saccharopolyspora erythraea. In addition, the genes were found in some $\alpha$ proteobacteria, primarily in some members of the Rhizobiales, including A. fabrum, Agrobacterium vitis, Agrobacterium radiobacter, Mesorhizobium loti, and Bradyrhizobium spp., with orthologs absent in genomes from related species. Such a sporadic distribution suggests acquisition by horizontal gene transfer (HGT). HGT would be expected to confer a fitness advantage, and it is important in the acquisition of virulence genes. A phylogenetic analysis of XdhR sequences showed that
XdhR from Actinomycetales and XdhR from Rhizobiales form separate clusters (Figure 3A).

Examination of the respective $x d h R$ promoters revealed conservation of a $22 \mathrm{bp}$ palindrome, predicted to be the XdhR binding site (Figure $3 \mathrm{~B}$ ). To map the position of this palindrome relative to $A$. fabrum $x d h C S M L$, mRNA isolated from stationary phase cells was used as a template for 5 -RACE to map the transcriptional start. Three distinct products were identified, indicating the existence of three start sites (Figure 2B). Sequencing of the longest and shortest products mapped the start site for the Long product $47 \mathrm{bp}$ upstream of the annotated translational start of $x d h C$, whereas the transcriptional start for the Short product was $94 \mathrm{bp}$ downstream.

The stringent response was induced by limiting inorganic phosphate, and ( $\mathrm{p}$ )ppGpp production was measured. A. fabrum was subcultured in phosphate-replete or -limiting medium containing ${ }^{32} \mathrm{P}$-labeled orthophosphate for $24 \mathrm{~h}$, and nucleotides were separated by TLC. ${ }^{33}$ In phosphate-starved cells, (p)ppGpp accumulated as expected, while cells grown in media containing abundant phosphate showed very little ( $\mathrm{p}$ )ppGpp synthesis (Figure 2D). Notably, analysis of gene expression showed that $x d h M$ was upregulated $15.6 \pm 4.1$-fold in phosphate-starved cells (Figure 2C). This upregulation is consistent with the expectation of increased purine salvage during the stringent response.

Conserved Regulation of $x d h C S M L$. In St. coelicolor, $\mathrm{XdhR}$ represses the operon encoding $\mathrm{Xdh}$, and derepression is achieved by direct binding of ( $p$ )ppGpp to XdhR, a binding event that leads to attenuated DNA binding by $\mathrm{XdhR}^{19}$ Considering the conservation of the genomic locus, we speculated that the regulatory mechanism might likewise be conserved; this would be of interest considering that ( $\mathrm{p}$ )ppGpp 
$\alpha 1$

E. coli TetR Rpalustris Bjaponicum Mloti

Aradiobacter Avitis

Afabrum Serythraea Scoelicolor Sgriseus Savermitilis

E. coli TetR Rpalustris Bjaponicum Mloti Aradiobacter Avitis Afabrum Serythraea Scoelicolor Sgriseus Savermitilis

E. coli TetR Rpalustris

Bjaponicum Mloti

Aradiobacter Avitis Afabrum Serythraea Scoelicolor Sgriseus Savermitilis

E. coli TetR Rpalustris Bjaponicum Mloti Aradiobacter Avitis Afabrum Serythraea Scoelicolor Sgriseus Savermitilis

$$
\begin{array}{ll}
1 & = \\
1 & = \\
1 & = \\
1 & = \\
1 & = \\
1 & \text { MS } \\
1 & = \\
1 & = \\
1 & = \\
1 & = \\
1 & -
\end{array}
$$

$\alpha 2$

$\alpha 3$

$\alpha 4$
MARLNRESVIDAALELLNETGI DGLTTR RADA QRNLKTLLDAALTVFATSGVEA-PVR 作 作 - - - MEREL ASKP STEPKDQTPPAGKSLRADARRNRDKL IETAAQAFADHGTAA-SLE MS SLVKP QL SR SRILA SAAS NTS SP KAP KMRADAORNREKLVEVAALAFAEKGVET-SLE

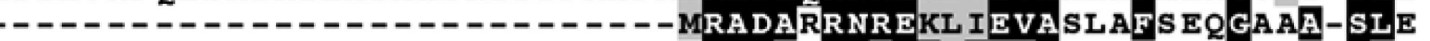
作作

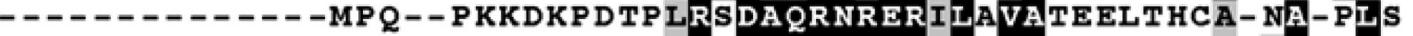
作 $\alpha 5$

29 KLAQKLGIEQPTLYWHVKNKRALLDALAVEILARHH D SLPAAGESWQSFLRNNA- -MS F 44 EI AEKAGVGIGTL T RHPQRSDLIVAV--..-- FRN GVDACAGAAAELAA S HAF EAL 47 AVAKRAGVGIGTLYRHFPTREDLFEAV------- YRREVEQLSELAEQLKNAKDSVDAL 51 EIARRA GVGIGTLY RHFP TREHLVEVV-.-.-- Y RREVEAL CAAAAELAQKHPS DVAL 54 DI ARRASVGVGTLY RHFPTREHLVEAV-------Y RHEVEALCDAAEELSRELTPDRTL 60 DI ARQAGVGIGTLY RHFOTREHLVEAV--.---- Y RREL S SLAEAATELATTLPADMAL 31 DI ARRAGVGIGTLYRHFP TREHLVESV------- Y RRELELLATAARDL IAEEEPAEAI 38 AI AKQA GVGVGTVY RHFP TPEELILAV-- - - - Y RREVRHLVEVVP SLLEAHPPE $Q$ AF 42 AI AKKA GVGQGTF I RNF P NREALVLEI-_. - - Y RY GMQQVAEAAP EMLATGEP DLAL 39 TI ARKAGVGQGTF T RNF PHREALVLEV-- - - - Y RY EMQQVADAAGELLRTRPP ERAL 44 AI AKKAGVGQGTF I RNF P NREALVLEI-_- - - I RY EMQQVADTAAQLLRTRAP DEAL

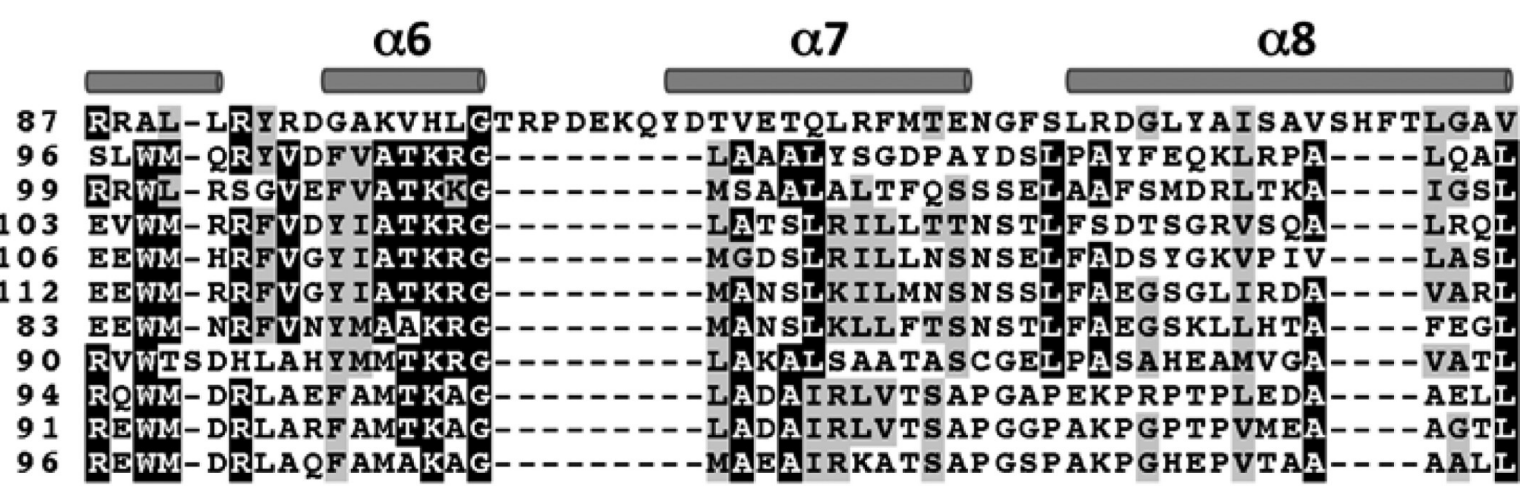

$\alpha 9$ $\alpha 10$

146 LEQQEHTAALT DRP AAP DENLP PLLREAL IMDS DDGEQAFLHGLESLIRGFEVQLTALL 142 LDAAGAAGEI- -RRDI EP FDLLKAVAQLCTSAPGGD-P AHTRRMVGLLIDGLRY RAGGAA 145 LDRAV AA GEM- -RADVS P EDLLRALI GMC YMH DQP GWQS SVLRML DV FVD GLRVQP GAKA 149 VEAAVADGTI- -RDDVDA SDVLHAL GGI I SAP DTPEWRDRS RRLV KLLMDGLRF GAGKG 152 IARAVADGSI- RADVDS TDVLHALSGT I SMP NS P EWHDRS RRLVGLLMD GLRWGAPRAS 158 MT KAQEQQLI- -RDDI GEADLLHALSS I Y SMP DT PEWRDRS HRLI GLLMDGLRH KG HP KA 129 LDNAVKADAV- -KGDI EAADVLNALFGI Y S I EGPEWRDRA HR IVRLVMD GLRR - - - 137 LEANVEAGTV--RADL DP ETVLR GL GGLL FLDPGGDWONOTANIT DLLWRGMITAD - - 140 LRANHEA GTI- -RP GVTGDDFFLVL GGLWL I P GENWQPRVTRFLDLVMDGLRAGAPGR137 LRACEEA GAV- -RP GVTP DDF FLAI A GLW QLD P REDWEPRA GR LL DF VMD GLRV GAA GR 142 LDANE SAGTI- -RP GVTP DDFILAI AGLWQIDPHGDWQPRAARLL DLVMDGLRT GARGR-

Figure 5. Conservation of $\mathrm{XdhR}$ proteins. Sequences of $\mathrm{XdhR}$ proteins from species included in Figure 3 compared to E. coli TetR. Secondary structure elements are from the structure of unliganded E. coli TetR (PDB entry 4V2F). The DNA recognition helix is $\alpha 3$. The ligand/dimerization domain is $\alpha 5-\alpha 10$; sequence conservation among $\mathrm{XdhR}$ proteins is consistent with shared ligand specificity. A few sequences were truncated at their C-termini.

generally has markedly different functions in Gram-positive and Gram-negative species.

The sequence of A. fabrum $\mathrm{XdhR}$ is most similar (46\% identical) to that of a TetR protein of unknown function from St. coelicolor [Protein Data Bank (PDB) entry 2Q24] among proteins for which structures have been reported, ${ }^{38}$ and this template was used to create a protein model. The model illustrates the conserved helix-turn-helix DNA binding domains, the position of a conserved tyrosine in DNA recognition helices, and the $\Omega$-shape that is characteristic of TetR proteins (Figure 4A). Conservation of sequence in recognition helices $(\alpha 3)$ is consistent with the presence of a 


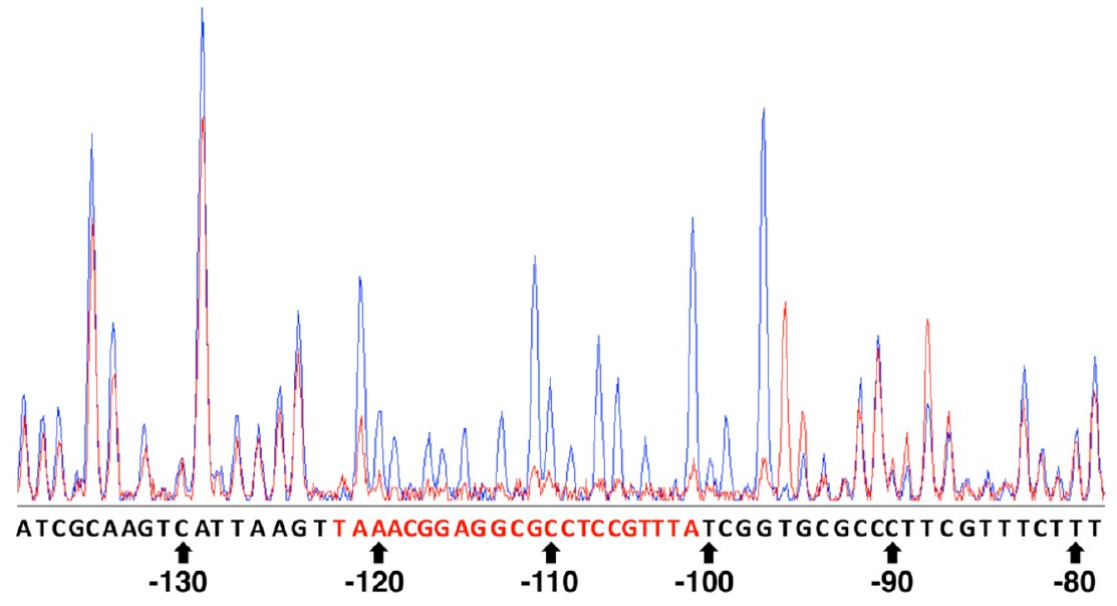

Figure 6. XdhR protects a site in the $x d h C S M L-x d h R$ intergenic region. Overlay of traces of digested intergenic DNA with (red) and without (blue) $\mathrm{XdhR}$. The sequence determined from the overlay of a Thermo Sequenase reaction is shown below with the identified palindrome colored red. The numbering is relative to the transcriptional start for $x d h C S M L$ (the Long product).

A

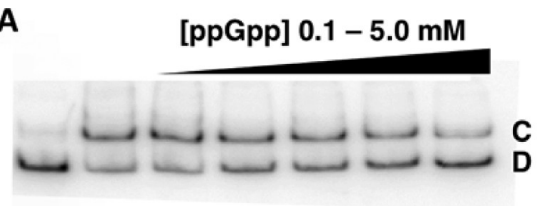

B

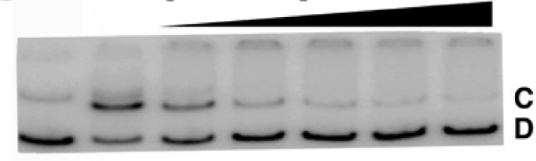

C

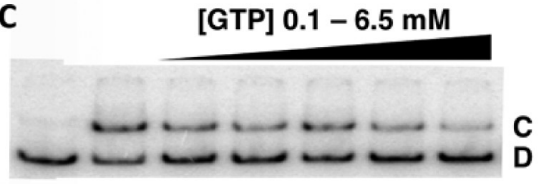

D

$\mathbf{F}$

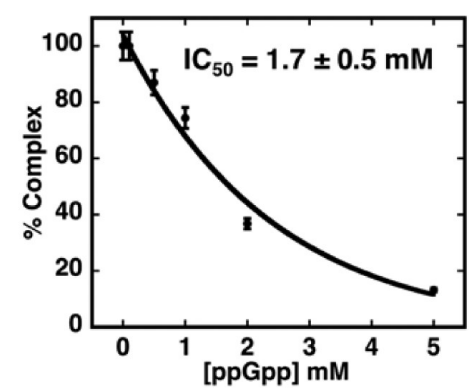

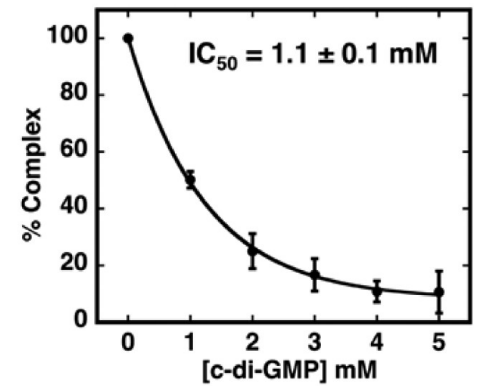

Figure 7. Ligands attenuate DNA binding by XdhR. Lanes 1 of each gel represent DNA only (D; 50 pM). Remaining reaction mixtures contained a constant protein concentration; reaction mixtures in lanes 2 contained DNA and protein. [XdhR] = 40, 40, 20, and 15 nM for panels A-D, respectively. Remaining lanes represent reaction mixtures with increasing concentrations of ligand. (A) ppGpp from 0.1 to $5 \mathrm{mM}$. (B) c-di-GMP from 0.1 to $5 \mathrm{mM}$. (C) GTP from 0.1 to $6.5 \mathrm{mM}$. (D) GMP from 0.5 to $30 \mathrm{mM}$. (E) Percent complex as a function of ppGpp concentration. (F) Percent complex as a function of c-di-GMP concentration.

conserved DNA site, whereas conservation of sequence in the ligand binding/dimerization lobe $(\alpha 5-\alpha 10)$ predicts shared ligand specificity for XdhR proteins; TetR proteins typically do not share sequence conservation outside the DNA binding helix-turn-helix motif, so this conservation suggests shared ligand specificities (Figure 5). ${ }^{39} \mathrm{XdhR}$ was overexpressed in $E$. coli, and the $22 \mathrm{kDa} \mathrm{N}$-terminal $\mathrm{His}_{6}$-tagged protein was purified to near homogeneity (Figure 4C). Size exclusion chromatography indicated that $\mathrm{XdhR}$ exists a dimer (Figure $4 \mathrm{~B}$ ), which is the most common oligomeric state of members of the TetR family of proteins in the absence of DNA. ${ }^{39}$

DNA containing the perfect $22 \mathrm{bp}$ palindrome in the $x d h C S M L-x d h R$ intergenic region was used for the EMSA. $\mathrm{XdhR}$ formed a single complex with a $K_{\mathrm{d}}$ of $9.2 \pm 0.1 \mathrm{nM}$ (Figure 4D,E). Upon addition of unlabeled specific DNA, the binding was attenuated, whereas addition of plasmid DNA did not affect the binding, indicating that $\mathrm{XdhR}$ binding was specific (Figure 4F; note that the highest concentration of specific 214 bp DNA corresponds to $2.1 \mu \mathrm{M}$ base pairs while the highest concentration of $6.3 \mathrm{~kb}$ nonspecific DNA corresponds to 44.1 $\mu \mathrm{M}$ base pairs). The binding site for $\mathrm{XdhR}$ was verified by DNaseI footprinting using $x d h R-x d h C$ intergenic DNA. Digested fragments from samples with and without protein were overlaid to identify the protected site, and sequences were identified by comparison to dideoxy cycle sequencing reactions (Figure 6). XdhR protected a site that spans $\sim 26 \mathrm{bp}$ starting $\sim 122$ bp upstream of the transcriptional start of $x d h C S M L$ (the Long product identified in Figure 2). This sequence corresponds to the $22 \mathrm{bp}$ perfect palindrome identified in the $x d h C S M L$ promoter (Figure $3 \mathrm{~B}$ ). Protection extended an additional $4 \mathrm{bp}$ beyond the palindrome (positions -97 to -100 relative to the transcriptional start of the $x d h C S M L$ Long product) followed by a hypersensitive site at position -96 (Figure 6).

Ligands ppGpp, c-di-GMP, and GTP Attenuate DNAXdhR Complex Formation. Several ligands were tested for their ability to attenuate DNA binding by XdhR using an EMSA. Intermediates in purine metabolism were tested on the 
basis of the role of $\mathrm{Xdh}$ in this metabolic pathway, along with guanosine derivatives ppGpp and $3^{\prime}, 5^{\prime}$-cyclic-di-GMP (c-diGMP) that are synthesized by enzymes that utilize GTP as their substrates. While xanthine (data not shown) and GMP (Figure 7D) very modestly attenuated DNA-XdhR binding, ppGpp, cdi-GMP, and GTP more effectively dissociated the complex. For ppGpp, the $K_{\mathrm{i}}$ was $0.3 \pm 0.1 \mathrm{mM}$; for c-di-GMP, the $K_{\mathrm{i}}$ was $0.2 \pm 0.01 \mathrm{mM}$, and for GTP, the $K_{\mathrm{i}}$ was $1.7 \pm 0.6 \mathrm{mM}$ (Figure $7 \mathrm{~A}-\mathrm{C}$; $K_{\mathrm{i}}$ values were calculated on the basis of $\left.\mathrm{IC}_{50}\right)$. Thus, ppGpp and c-di-GMP were the most efficient ligands for XdhR, with GTP attenuating binding with a lower efficiency. Adenine, guanine, hypoxanthine, and urate did not affect XdhR-DNA binding (data not shown). Notably, accumulation of (p)ppGpp (Figure 2D) correlated with induction of $x d h M$ (Figure 2C), consistent with ( $\mathrm{p}$ )ppGpp functioning as a preferred $\mathrm{XdhR}$ ligand during stringent response. Detection of c-di-GMP has been accomplished using two-dimensional TLC; ${ }^{40}$ however, under conditions of phosphate limitation, we did not detect accumulation of this guanosine derivative (data not shown).

Allopurinol, an analogue of hypoxanthine, is an inhibitor of $\mathrm{Xdh} .{ }^{41}$ Because Xdh participates in purine salvage to promote formation of guanosine nucleotides, inhibition of $\mathrm{Xdh}$ would be expected to attenuate their accumulation. Considering that $\mathrm{XdhR}$ responds most efficiently to highly phosphorylated guanosine nucleotides by attenuated DNA binding, we assessed if inhibition of $\mathrm{Xdh}$ would be associated with repression of $x d h C S M L$ expression. When exponentially growing A. fabrum was treated with allopurinol, the level of $x d h M$ expression was reduced to $\sim 50 \%$ of that in the unsupplemented culture $1 \mathrm{~h}$ after addition of allopurinol; $2 \mathrm{~h}$ after the addition of allopurinol, expression levels approached levels observed in unsupplemented cultures (Figure 8). This would be consistent

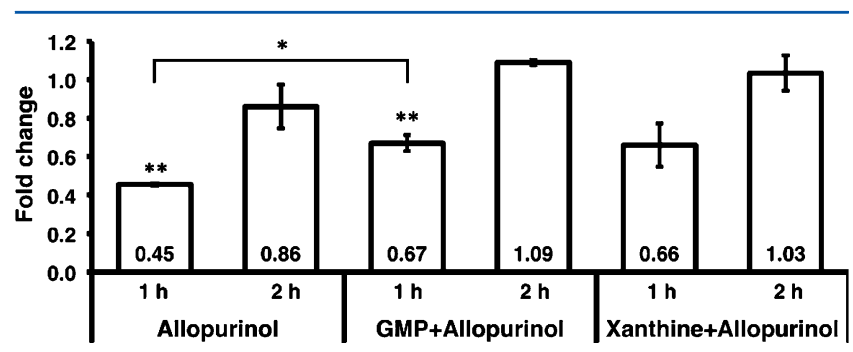

Figure 8. Relative $x d h M$ transcript level after addition of allopurinol analyzed by qRT-PCR. Cultures were supplemented with $10 \mathrm{mM}$ allopurinol or with $10 \mathrm{mM}$ allopurinol and $10 \mathrm{mM}$ GMP or xanthine, and cells were harvested at the indicated times. Transcript levels relative to unsupplemented cultures are reported and correspond to means \pm SD of two independent experiments. Asterisks directly above the bars indicate a statistically significant difference $(* * p<0.01)$ compared to unsupplemented cultures based on a two-tailed Student's $t$ test. Expression $1 \mathrm{~h}$ after the addition of both allopurinol and GMP is statistically different $(* p<0.05)$ from expression after addition of allopurinol only. Differences in expression levels after 1 and $2 \mathrm{~h}$ are statistically significant as determined by a two-way analysis of variance $(p<0.001)$.

with inhibition of Xdh leading to attenuated production of GTP, a ligand for XdhR. If a lower level of $x d h M$ expression is due to $\mathrm{Xdh}$ inhibition leading to reduced production of phosphorylated guanine nucleotides, we reasoned that xanthine and guanine might reverse the effect. Indeed, addition of GMP $(10 \mathrm{mM})$ or xanthine $(10 \mathrm{mM})$ along with allopurinol mitigated the inhibitory effect of allopurinol (Figure 8).
The Stringent Response Does Not Lead to Accumulation of Urate or Induction of PecS Target Genes. Xdh biases purine salvage toward synthesis of guanosine nucleotides; however, it also catalyzes the first committed step in purine catabolism by converting xanthine to urate. Thus, a competition between purine salvage and catabolism exists, with the outcome determined by the predominant fate of xanthine (Figure 1A). Should urate accumulate under conditions of increased Xdh activity, expression of pecS and pecM genes would be expected; genes encoding PecS are conserved in select bacterial pathogens, and they are encoded divergently from pecM, which encodes an efflux pump that in $D$. dadantii was shown to export the antioxidant indigoidine. ${ }^{23,42}$ Several PecS proteins have been shown to bind urate, which results in attenuated DNA binding and expression of genes otherwise repressed by PecS (Figure 1B). 27,28,43,44

Enhanced expression of the $x d h C S M L$ operon correlates with accumulation of (p)ppGpp (Figure 2C,D), suggesting that purine salvage (synthesis of guanosine nucleotides) may be favored over purine catabolism. Consistent with this inference, no increase in the level of pecS/pecM expression was observed under phosphate starvation; rather, the level of expression was modestly reduced (Figure 9A). Urate levels were also compared
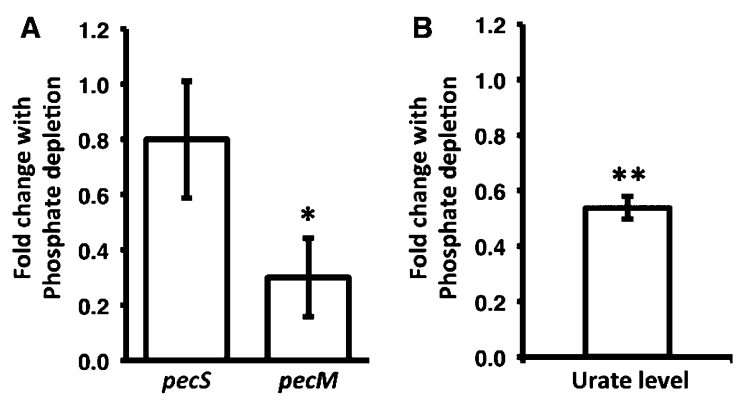

Figure 9. Phosphate starvation does not lead to urate accumulation or induction of pecS and pecM. (A) The pecS and pecM transcript levels determined by qRT-PCR after phosphate starvation for $24 \mathrm{~h}$ relative to cells grown with ample phosphate (mean \pm SD from two independent experiments). (B) Relative cellular urate content determined using the Amplex Red Uric Acid Assay Kit in cells grown for $24 \mathrm{~h}$ under phosphate starvation relative to cells grown with ample phosphate (mean \pm SD from three independent experiments). Asterisks indicate a statistically significant difference $(* * p<0.01$; $* p<0.05)$ for phosphate-starved compared to phosphate-sufficient cultures based on a two-tailed Student's $t$ test.

in phosphate-starved cells and in cells grown with sufficient phosphate; consistent with the modestly reduced level of pecS/ pecM expression, urate levels were found to decrease $\sim 50 \%$ under phosphate starvation (Figure 9B).

In plants, the extent of purine catabolism is increased during the defense against pathogens as urate functions as an antioxidant to protect plant cells against oxidative stress. ${ }^{22}$ As reported previously, ${ }^{28}$ addition of urate to A. fabrum cultures resulted in an $\sim 15$-fold increase in the level of expression of pecS/pecM (Figure 10A). Taken together, we infer that it is plant-derived urate that functions as a PecS ligand, not bacterially derived urate.

Genes under PecS Control Are Not Induced by Acidic pH. In A. fabrum, transfer of T-DNA requires induction of vir genes by plant-derived phenolic compounds in an acidic environment, at a $\mathrm{pH}$ that corresponds to that of the rhizosphere and the site of infection. Such acidic conditions 

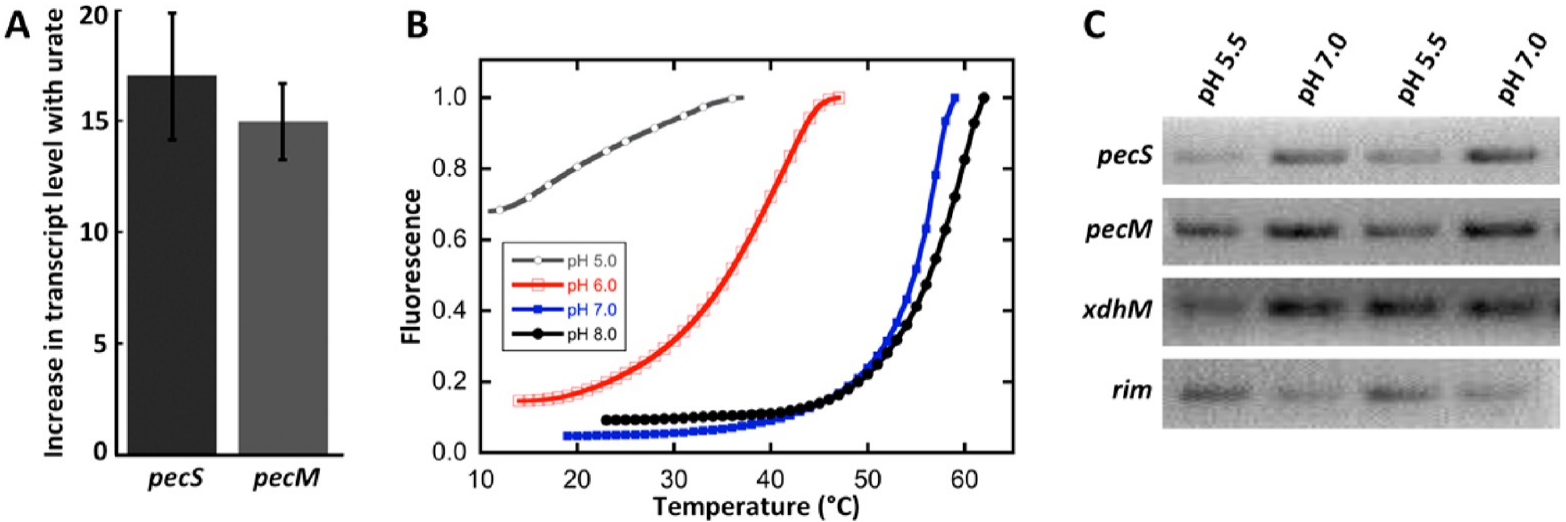

Figure 10. pecS and pecM are induced by urate, but not by acidic $\mathrm{pH}$. (A) Fold induction of pecS and pecM after the culture medium had been supplemented with $10 \mathrm{mM}$ urate. ${ }^{28}$ (B) Thermal stability of PecS measured by SYPRO Orange fluorescence resulting from binding of the dye to hydrophobic patches of unfolded protein. Normalized fluorescence as a function of temperature at $\mathrm{pH} 8.0$ (black, filled circles), $\mathrm{pH} 7.0$ (blue, filled squares), $\mathrm{pH} 6.0$ (red, empty squares), and $\mathrm{pH} 5.0$ (gray, empty circles). (C) Amplified cDNA corresponding to genes identified at the left at $\mathrm{pH} 5.5$ and 7.0. Biological replicates are shown. Gels were stained with ethidium bromide.

also induce a number of chromosomally encoded virulence genes. We therefore considered if $A$. fabrum PecS also regulates target genes in response to changes in extracellular $\mathrm{pH}$. A. fabrum PecS is a dimer in which each monomer features eight histidine residues (Figure $1 \mathrm{~B}$ ); given a predicted $\mathrm{p} K_{\mathrm{a}}$ of $\sim 6.5$ of surface-exposed His, PecS would have the potential to sense transient reductions in intracellular $\mathrm{pH}$.

As expected from the abundance of His residues, the PecS stability was $\mathrm{pH}$-dependent (Figure $10 \mathrm{~B}$ ). PecS was quite stable at $\mathrm{pH} 8.0$ and $7.0\left(T_{\mathrm{m}}\right.$ values of $55.6 \pm 0.4$ and $54.0 \pm 1.1^{\circ} \mathrm{C}$, respectively). At $\mathrm{pH} 6.0$, the $T_{\mathrm{m}}$ was reduced to $38.8 \pm 0.3{ }^{\circ} \mathrm{C}$, consistent with a change in the protonation state of His, whereas the protein appeared to be largely unfolded at $\mathrm{pH} 5.0$ in absence of DNA, as evidenced by a very high fluorescence at the start of the thermal scan. However, reducing the extracellular $\mathrm{pH}$ from 7.0 to 5.5 did not markedly change pecS/pecM expression (Figure 10C).

PecS was previously shown to bind a single palindrome in the pecS promoter that is located $14 \mathrm{bp}$ upstream of the start codon [site 1 (Figure 11)] and as a dimer to site 2, which consists of two overlapping palindromes that extend into the coding sequence of pecM; the apparent macroscopic $K_{\mathrm{d}}$ for binding to the pecS-pecM DNA was $0.4 \mathrm{nM}^{28}$ At a substoichiometric PecS:DNA ratio of $2: 1$, site 1 was fully protected at $\mathrm{pH} 7.4$, whereas protection of site 2 was partial (Figure 11). By contrast, a higher PecS:DNA ratio was required for protection at $\mathrm{pH}$ 5.0, although site 1 was still more completely protected than site 2 . This suggests a reduced affinity of PecS for cognate DNA at a lower $\mathrm{pH}$, but no other apparent change in the mode of binding (e.g., no change in specificity).

\section{DISCUSSION}

A Competition between Enzymes That Use Xanthine as Their Substrate. While the level of $x d h C S M L$ expression is increased under conditions of phosphate limitation, urate levels decrease, perhaps reflecting the fact that xanthine is preferentially converted to XMP and subsequently to guanosine nucleotides rather than catabolized to urate. This competition between enzymes that use xanthine as their substrate, the salvage enzyme xanthine-guanine phosphoribosyltransferase (XGPRT) that converts xanthine to XMP (encoded by Atu1731) and Xdh, may depend on both relative affinities for
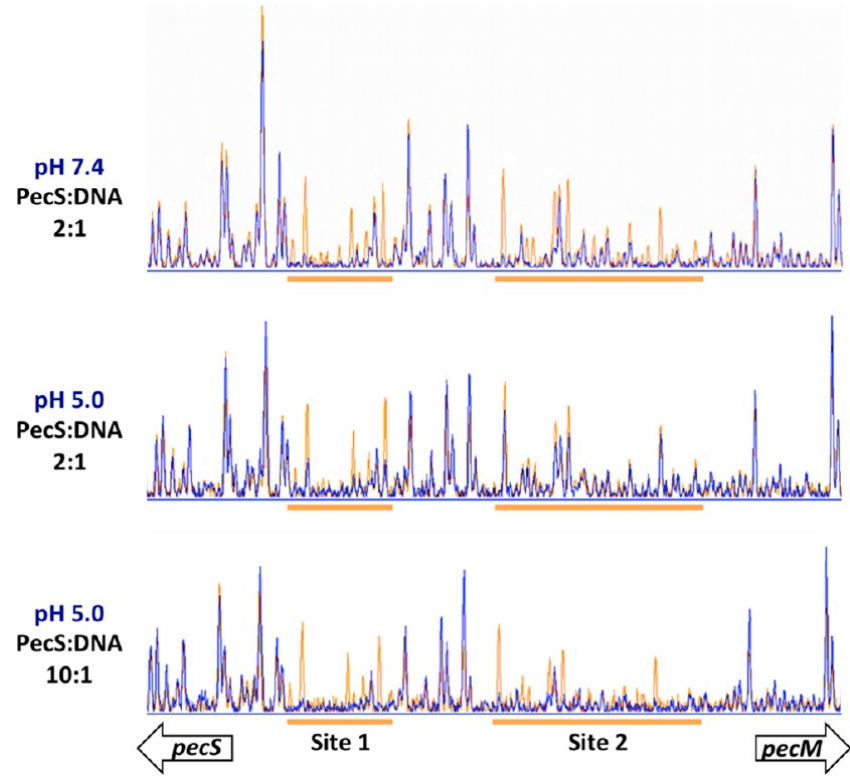

Figure 11. PecS protects cognate sites at $\mathrm{pH} 5.0$ with a reduced affinity. Overlay of traces of digested pecS-pecM DNA without (orange) and with (blue) PecS. Reactions performed at $\mathrm{pH} 7.4$ (top) or $\mathrm{pH} 5.0$ (middle and bottom) with $14 \mathrm{nM}$ DNA (i.e., performed under stoichiometric conditions for $\mathrm{pH} 7.4$, where $K_{\mathrm{d}} \sim 0.4 \mathrm{nM}$ ). PecS:DNA ratios are shown at the left. The directions of pecS and pecM genes are shown by arrows. Site 1 contains a single palindrome, and site 2 contains two palindromes that overlap by $3 \mathrm{bp}{ }^{28}$

the substrate and expression of the respective genes. A comparison of bacterial XGPRT and Xdh enzymes for which kinetic parameters have been reported suggests comparable $K_{\mathrm{M}}$ values, for example, a $K_{\mathrm{M}}$ for xanthine of $E$. coli XGPRT of $\sim 30$ $\mu \mathrm{M}$ and a $K_{\mathrm{M}}$ for xanthine of Rhodobacter capsulatus Xdh of $\sim 65 \mu \mathrm{M}^{45,46}$ In Bacillus subtilis, the nutritional state reciprocally controls expression of genes encoding XGPRT and $\mathrm{Xdh}$; when purines are present, but ammonium ions are absent, the gene encoding $\mathrm{Xdh}$ is expressed while purines repress expression of an operon encoding XGPRT, suggesting the need for purine catabolism. Conversely, XGPRT is expressed when a nitrogen source is available, promoting purine salvage. ${ }^{47}$ For $A$. fabrum, it remains to be determined 
whether its Xdh and XGPRT enzymes have different $K_{M}$ values for xanthine and/or if the gene encoding XGPRT is induced during the stringent response to favor synthesis of phosphorylated guanosine derivatives.

PecS Target Gene Expression Is Likely Induced by Host-Derived Urate. An acidic $\mathrm{pH}$ promotes vir gene expression, but not pecS/pecM expression (Figure 10). This is in contrast to $P$. atrosepticum PecS, for which changes in extracellular $\mathrm{pH}$ alter the activity of the pecS promoter. ${ }^{27}$ At $\mathrm{pH}$ 5.5, the affinity of PecS appears to be reduced; because the overall protection of the three palindromes that constitute PecS sites 1 and 2 looks $<50 \%$ complete with $28 \mathrm{nM} \mathrm{PecS} \mathrm{[a}$ PecS:DNA ratio of $2: 1$ (Figure 11, middle panel)], a macroscopic dissociation constant near $28 \mathrm{nM}$ is plausible. The exact $K_{\mathrm{d}}$ notwithstanding, a reduced affinity would be expected to result in facilitated induction by urate should the intracellular $\mathrm{pH}$ transiently decrease, perhaps contributing to induction of the PecS regulon at an external $\mathrm{pH}$ corresponding to that of the site of infection.

Because purine catabolism appears to be disfavored during the stringent response, as evidenced by the absence of urate accumulation, we infer that induction of PecS target genes is likely to require purine catabolism in the host. Indeed, plant $\mathrm{Xdh}$ activity is increased during infection, resulting in accumulation of xanthine along with generation of reactive oxygen species; notably, production of urate was linked to protection of surrounding plant cells from oxidative damage, indicating a dual role for plant $\mathrm{Xdh} .{ }^{22}$ Considering the increased activity of host Xdh during infection, bacteria colonizing plant tissue will encounter elevated levels of both xanthine and urate.

Conservation of Divergent Genes Encoding Xdh and XdhR. In St. coelicolor, the $x d h$ operon consists of four open reading frames with the $\mathrm{XdhC}$ chaperone encoded last. A similar organization of open reading frames is seen in A. vitis, in which the genes are encoded on chromosome 1. By contrast, $x d h C$ precedes $x d h S M L$ in A. fabrum (Figure $2 \mathrm{~A}$ ), and in $A$. radiobacter, no $x d h C$ gene is encoded in the context of the divergent $x d h R-x d h S M L$ genes. $\mathrm{XdhC}$ chaperones encoded as part of Xdh-encoding operons may be dedicated to the corresponding enzyme, whereas $\mathrm{XdhC}$ proteins that are not encoded as part of an operon may serve as chaperones for several molybdoenzymes. However, only XdhC from $R$. capsulatus has been characterized, ${ }^{48}$ and specific functions therefore remain speculative.

Three transcriptional start sites were identified for $x d h C$, of which the most prominent was $94 \mathrm{bp}$ downstream of the annotated translational start codon (Figure 2B). The significance of this observation also remains unclear, but we note that the identified start sites correspond to transcripts isolated during the stationary phase; it is conceivable that promoter utilization and hence transcriptional start sites differ during exponential growth, when the level of $x d h C S M L$ expression is lower. Whether the position of transcriptional starts correlates with differential utilization of translational start codons and/or if the function of $\mathrm{XdhC}$ is modulated on the basis of the length of its $\mathrm{N}$-terminal segment also awaits determination; however, we note that the annotation of XdhC proteins from Rhizobiaceae predicts $\mathrm{N}$-terminal extensions of variable length preceding the core $\mathrm{XdhC}$ domain that is identified by PFAM. For example, the annotated $\mathrm{XdhC}$ from $A$. tumefaciens LBA4404 is identical to that from A. fabrum C58, except that it is missing 18 amino acids from the $\mathrm{N}$-terminus.
Regulation of $x d h C S M L$ by XdhR. A. fabrum XdhR is homologous to St. coelicolor XdhR, which binds the intergenic region between genes encoding $\mathrm{XdhR}$ and $\mathrm{Xdh}$, repressing both. $^{18,19}$ St. coelicolor XdhR, which differs in being a tetramer in the absence of DNA, binds preferred sites in the $x d h R$ promoter, distant from the operon encoding $\mathrm{Xdh}$, and a looping model was proposed in which an XdhR dimer binding to the $x d h R$ gene leads to a DNA looping around a bending protein (perhaps HU), resulting in the other dimer of the XdhR tetramer binding to a less conserved site in the $x d h$ gene promoter; this inference was supported by partial protection of this site at higher protein concentrations. ${ }^{19}$ By comparison, $A$. fabrum XdhR protects a site that is centered $\sim 110$ bp upstream of the $x d h C$ transcriptional start [the Long product (Figure 2B)] and $95 \mathrm{bp}$ upstream of the annotated translational start codon for $x d h R$. While it is conceivable that dimeric A. fabrum $\mathrm{XdhR}$ similarly oligomerizes in vivo to autoregulate its own expression along with that of the $x d h C S M L$ gene cluster, we did not observe oligomerization of $\mathrm{XdhR}$ in solution (Figure $4 \mathrm{~B}$ ). Using a stoichiometric excess of XdhR, protection of $x d h R-$ $x d h C$ intergenic DNA that included $69 \mathrm{bp}$ of the annotated $x d h C$ open reading frame also did not reveal protection beyond the cognate site in the $x d h R$ promoter. However, a site that conserves $13 \mathrm{bp}$ of the $22 \mathrm{bp}$ palindrome near the $x d h \mathrm{R}$ gene was identified immediately upstream of the identified start site for the Short transcript [94 bp downstream of the annotated translational start (Figure 2B)]; XdhR binding at this position would be consistent with repression of $x d h C$, regardless of transcriptional start.

Expression of $x d h C S M L$ Is Induced by ppGpp and cdi-GMP. Deletion of enzymes in the purine salvage pathway has been linked to failure to synthesize (p)ppGpp and to reduced virulence. ${ }^{17,49,50}$ Similarly, in the Gram-positive St. coelicolor, inhibition of $\mathrm{Xdh}$ leads to a reduced level of (p)ppGpp accumulation, while upregulation of genes encoding Xdh correlates with enhanced (p)ppGpp synthesis. ${ }^{19}$ Xdh plays a unique role in purine salvage as it participates in conversion of adenine nucleotides to guanine nucleotides, rationalizing its importance under conditions that require synthesis of guanosine-based signaling molecules (Figure 1A). In Grampositive organisms, a significant role of ( $\mathrm{p}$ ) ppGpp is to control GTP homeostasis, and the increase in ( $\mathrm{p}$ )ppGpp levels during the stringent response has been shown to result in markedly reduced levels of GTP. ${ }^{16,51}$ It was therefore proposed that regulation of the operon encoding St. coelicolor Xdh primarily serves to ensure GTP homeostasis. The data presented here show that the regulatory feedback between purine salvage and $\mathrm{Xdh}$ production is conserved in a Gram-negative species, despite fundamentally different functions of ( $p$ )ppGpp.

During the exponential growth of E. coli, millimolar concentrations of GTP may accumulate in cells while (p)ppGpp levels are negligible, and during the stringent response, GTP is reduced only $\sim 50 \%$ whereas (p)ppGpp levels may reach millimolar concentrations. ${ }^{52-54}$ Assuming similar cellular concentrations of GTP and (p)ppGpp in A. fabrum, the observed $K_{\mathrm{i}}$ for GTP $(1.7 \mathrm{mM})$ and ppGpp (0.3 $\mathrm{mM}$ ) would be physiologically relevant. Because $x d h M$ is significantly upregulated during the stringent response, our data are consistent with (p)ppGpp acting as a higher-affinity ligand for XdhR. GTP being a lower-affinity ligand would result in a modest induction of the $x d h C S M L$ gene cluster that is sufficient for maintaining GTP levels during exponential growth when the de novo purine synthesis would also contribute to GTP 
production; the modestly reduced level of expression of $x d h M$ that occurs as a consequence of inhibiting Xdh with allopurinol and the ability to bypass this inhibition by addition of other purines support this interpretation. Similarly, it was previously reported that the requirement for $\mathrm{Xdh}$ in the utilization of guanine precursors in Rhizobium tropici is circumvented upon addition of xanthine and guanine. ${ }^{55}$ During the stringent response, the enzymes required for de novo synthesis would be inhibited, placing greater demands on salvage pathways. ${ }^{51}$ Thus, Xdh becomes critical for replenishing the GTP pool to sustain (p)ppGpp synthesis. Consistent with this interpretation, the genes encoding S. meliloti Xdh are upregulated in a RelA- and DksA-dependent manner during carbon and nitrogen starvation. $^{13}$

c-di-GMP is a common second messenger that participates in the transition from a motile to a sessile (or biofilm) lifestyle, with high levels of c-di-GMP generally favoring a sessile state and surface attachment. ${ }^{56}$ For A. fabrum, attachment to plant surfaces is a required step in the infection cycle, and increased levels of c-di-GMP have been implicated in this process. ${ }^{57,58} \mathrm{c}$ di-GMP is synthesized from two GTP molecules by diguanylate cyclases, which would rationalize the need to increase the level of purine salvage under conditions of c-di-GMP synthesis, and it suggests an additional reason why co-transmission of the At plasmid promotes plant colonization. Taken together, our data suggest that A. fabrum XdhR is a direct target for guanosinederived signaling molecules and that a positive feedback loop is established in which purine salvage is upregulated by signaling molecules that depend on GTP for their synthesis.

\section{AUTHOR INFORMATION}

\section{Corresponding Author}

*Department of Biological Sciences, Louisiana State University, Baton Rouge, LA 70803. Telephone: 225-578-5148. E-mail: agrove@lsu.edu.

\section{ORCID $\odot$}

Dinesh K. Deochand: 0000-0002-7395-9250

Anne Grove: 0000-0002-4390-0354

\section{Present Addresses}

${ }^{\dagger}$ S.S.: Nanyang Technological University, Singapore.

${ }^{\ddagger}$ D.K.D.: Hospital for Special Surgery and Weill Cornell Medical College, New York, NY 10021.

${ }^{\S}$ J.K.M.: Louisiana State University Health Sciences Center, New Orleans, LA 70112.

\section{Funding}

Supported by the National Science Foundation (MCB-1515349 to A.G.).

\section{Notes}

The authors declare no competing financial interest.

\section{ACKNOWLEDGMENTS}

The authors thank Marcia Newcomer for the use of her FPLC system.

\section{REFERENCES}

(1) Mansfield, J., Genin, S., Magori, S., Citovsky, V., Sriariyanum, M., Ronald, P., Dow, M., Verdier, V., Beer, S. V., Machado, M. A., Toth, I., Salmond, G., and Foster, G. D. (2012) Top 10 plant pathogenic bacteria in molecular plant pathology. Mol. Plant Pathol. 13, 614-629.

(2) Platt, T. G., Morton, E. R., Barton, I. S., Bever, J. D., and Fuqua, C. (2014) Ecological dynamics and complex interactions of Agrobacterium megaplasmids. Front. Plant Sci. 5, 635.
(3) Pitzschke, A. (2013) Agrobacterium infection and plant defensetransformation success hangs by a thread. Front. Plant Sci. 4, 519.

(4) Li, L., Jia, Y., Hou, Q., Charles, T. C., Nester, E. W., and Pan, S. Q. (2002) A global pH sensor: Agrobacterium sensor protein ChvG regulates acid-inducible genes on its two chromosomes and $\mathrm{Ti}$ plasmid. Proc. Natl. Acad. Sci. U. S. A. 99, 12369-12374.

(5) Xu, J., Kim, J., Danhorn, T., Merritt, P. M., and Fuqua, C. (2012) Phosphorus limitation increases attachment in Agrobacterium tumefaciens and reveals a conditional functional redundancy in adhesin biosynthesis. Res. Microbiol. 163, 674-684.

(6) Yuan, Z. C., Liu, P., Saenkham, P., Kerr, K., and Nester, E. W. (2008) Transcriptome profiling and functional analysis of Agrobacterium tumefaciens reveals a general conserved response to acidic conditions ( $\mathrm{pH}$ 5.5) and a complex acid-mediated signaling involved in Agrobacterium-plant interactions. J. Bacteriol. 190, 494-507.

(7) Gaca, A. O., Colomer-Winter, C., and Lemos, J. A. (2015) Many means to a common end: the intricacies of (p)ppGpp metabolism and its control of bacterial homeostasis. J. Bacteriol. 197, 1146-1156.

(8) Liu, K., Bittner, A. N., and Wang, J. D. (2015) Diversity in (p)ppGpp metabolism and effectors. Curr. Opin. Microbiol. 24, 72-79.

(9) Mittenhuber, G. (2001) Comparative genomics and evolution of genes encoding bacterial (p)ppGpp synthetases/hydrolases (the Rel, RelA and SpoT proteins). J. Mol. Microbiol. Biotechnol. 3, 585-600.

(10) Vercruysse, M., Fauvart, M., Jans, A., Beullens, S., Braeken, K., Cloots, L., Engelen, K., Marchal, K., and Michiels, J. (2011) Stress response regulators identified through genome-wide transcriptome analysis of the (p)ppGpp-dependent response in Rhizobium etli. Genome Biol. 12, R17.

(11) Wells, D. H., and Long, S. R. (2002) The Sinorhizobium meliloti stringent response affects multiple aspects of symbiosis. Mol. Microbiol. $43,1115-1127$.

(12) Belitsky, B., and Kari, C. (1982) Absence of accumulation of ppGpp and RNA during amino acid starvation in Rhizobium meliloti. J. Biol. Chem. 257, 4677-4679.

(13) Krol, E., and Becker, A. (2011) ppGpp in Sinorhizobium meliloti: biosynthesis in response to sudden nutritional downshifts and modulation of the transcriptome. Mol. Microbiol. 81, 1233-1254.

(14) My, L., Rekoske, B., Lemke, J. J., Viala, J. P., Gourse, R. L., and Bouveret, E. (2013) Transcription of the Escherichia coli fatty acid synthesis operon fabHDG is directly activated by FadR and inhibited by ppGpp. J. Bacteriol. 195, 3784-3795.

(15) Geiger, T., and Wolz, C. (2014) Intersection of the stringent response and the CodY regulon in low GC Gram-positive bacteria. Int. J. Med. Microbiol. 304, 150-155.

(16) Kriel, A., Brinsmade, S. R., Tse, J. L., Tehranchi, A. K., Bittner, A. N., Sonenshein, A. L., and Wang, J. D. (2014) GTP dysregulation in Bacillus subtilis cells lacking (p)ppGpp results in phenotypic amino acid auxotrophy and failure to adapt to nutrient downshift and regulate biosynthesis genes. J. Bacteriol. 196, 189-201.

(17) Xi, H., Schneider, B. L., and Reitzer, L. (2000) Purine catabolism in Escherichia coli and function of xanthine dehydrogenase in purine salvage. J. Bacteriol. 182, 5332-5341.

(18) Hillerich, B., and Westpheling, J. (2008) A new TetR family transcriptional regulator required for morphogenesis in Streptomyces coelicolor. J. Bacteriol. 190, 61-67.

(19) Sivapragasam, S., and Grove, A. (2016) Streptomyces coelicolor $\mathrm{XdhR}$ is a direct target of (p)ppGpp that controls expression of genes encoding xanthine dehydrogenase to promote purine salvage. Mol. Microbiol. 100, 701-718.

(20) Enroth, C., Eger, B. T., Okamoto, K., Nishino, T., Nishino, T., and Pai, E. F. (2000) Crystal structures of bovine milk xanthine dehydrogenase and xanthine oxidase: structure-based mechanism of conversion. Proc. Natl. Acad. Sci. U. S. A. 97, 10723-10728.

(21) Werner, A. K., and Witte, C. P. (2011) The biochemistry of nitrogen mobilization: purine ring catabolism. Trends Plant Sci. 16, $381-387$.

(22) Ma, X., Wang, W., Bittner, F., Schmidt, N., Berkey, R., Zhang, L., King, H., Zhang, Y., Feng, J., Wen, Y., Tan, L., Li, Y., Zhang, Q., Deng, Z., Xiong, X., and Xiao, S. (2016) Dual and Opposing Roles of 
Xanthine Dehydrogenase in Defense-Associated Reactive Oxygen Species Metabolism in Arabidopsis. Plant Cell 28, 1108-1126.

(23) Perera, I. C., and Grove, A. (2011) MarR homologs with uratebinding signature. Protein Sci. 20, 621-629.

(24) Deochand, D. K., and Grove, A. (2017) MarR family transcription factors: Dynamic variations on a common scaffold. Crit. Rev. Biochem. Mol. Biol., n/a.

(25) Hommais, F., Oger-Desfeux, C., Van Gijsegem, F., Castang, S., Ligori, S., Expert, D., Nasser, W., and Reverchon, S. (2008) PecS is a global regulator of the symptomatic phase in the phytopathogenic bacterium Erwinia chrysanthemi 3937. J. Bacteriol. 190, 7508-7522.

(26) Pedron, J., Chapelle, E., Alunni, B., and Van Gijsegem, F. (2017) Transcriptome analysis of the Dickeya dadantii PecS regulon during the early stages of interaction with Arabidopsis thaliana. Mol. Plant Pathol., n/a.

(27) Deochand, D. K., Meariman, J. K., and Grove, A. (2016) pHDependent DNA Distortion and Repression of Gene Expression by Pectobacterium atrosepticum PecS. ACS Chem. Biol. 11, 2049-2056.

(28) Perera, I. C., and Grove, A. (2010) Urate is a ligand for the transcriptional regulator PecS. J. Mol. Biol. 402, 539-551.

(29) Grove, A., Kushwaha, A. K., and Nguyen, K. H. (2015) Determining the role of metal binding in protein cage assembly. Methods Mol. Biol. 1252, 91-100.

(30) Deochand, D. K., Perera, I. C., Crochet, R. B., Gilbert, N. C., Newcomer, M. E., and Grove, A. (2016) Histidine switch controlling $\mathrm{pH}$-dependent protein folding and DNA binding in a transcription factor at the core of synthetic network devices. Mol. BioSyst. 12, 24172426.

(31) Cheng, Y., and Prusoff, W. H. (1973) Relationship between the inhibition constant (K1) and the concentration of inhibitor which causes $50 \%$ inhibition (I50) of an enzymatic reaction. Biochem. Pharmacol. 22, 3099-3108.

(32) Sivapragasam, S., Pande, A., and Grove, A. (2015) A recommended workflow for DNase I footprinting using a capillary electrophoresis genetic analyzer. Anal. Biochem. 481, 1-3.

(33) Sivapragasam, S., and Grove, A. (2016) Determination of (p)ppGpp Levels During Stringent Response in Streptomyces coelicolor by Thin Layer Chromatography. Bio-Protoc. 6, e1995.

(34) Calderon-Flores, A., Du Pont, G., Huerta-Saquero, A., Merchant-Larios, H., Servin-Gonzalez, L., and Duran, S. (2005) The stringent response is required for amino acid and nitrate utilization, nod factor regulation, nodulation, and nitrogen fixation in Rhizobium etli. J. Bacteriol. 187, 5075-5083.

(35) Leimkuhler, S., and Iobbi-Nivol, C. (2016) Bacterial molybdoenzymes: old enzymes for new purposes. FEMS Microbiol Rev. 40, 1-18.

(36) Lang, J., Planamente, S., Mondy, S., Dessaux, Y., Morera, S., and Faure, D. (2013) Concerted transfer of the virulence Ti plasmid and companion At plasmid in the Agrobacterium tumefaciens-induced plant tumour. Mol. Microbiol. 90, 1178-1189.

(37) Franceschini, A., Szklarczyk, D., Frankild, S., Kuhn, M., Simonovic, M., Roth, A., Lin, J., Minguez, P., Bork, P., von Mering, C., and Jensen, L. J. (2013) STRING v9.1: protein-protein interaction networks, with increased coverage and integration. Nucleic Acids Res. 41, D808-D815.

(38) Filippova, E. V., Chruszcz, M., Cymborowski, M., Gu, J., Savchenko, A., Edwards, A., and Minor, W. (2011) Crystal structure of a putative transcriptional regulator SCO0520 from Streptomyces coelicolor A3(2) reveals an unusual dimer among TetR family proteins. J. Struct. Funct. Genomics 12, 149-157.

(39) Cuthbertson, L., and Nodwell, J. R. (2013) The TetR family of regulators. Microbiol Mol. Biol. Rev. 77, 440-475.

(40) Tischler, A. D., and Camilli, A. (2004) Cyclic diguanylate (c-diGMP) regulates Vibrio cholerae biofilm formation. Mol. Microbiol. 53, 857-869.

(41) Truglio, J. J., Theis, K., Leimkuhler, S., Rappa, R., Rajagopalan, K. V., and Kisker, C. (2002) Crystal structures of the active and alloxanthine-inhibited forms of xanthine dehydrogenase from Rhodobacter capsulatus. Structure 10, 115-125.
(42) Rouanet, C., and Nasser, W. (2001) The PecM protein of the phytopathogenic bacterium Erwinia chrysanthemi, membrane topology and possible involvement in the efflux of the blue pigment indigoidine. J. Mol. Microbiol. Biotechnol. 3, 309-318.

(43) Wang, Z. C., Liu, C. J., Huang, Y. J., Wang, Y. S., and Peng, H. L. (2015) PecS regulates the urate-responsive expression of type 1 fimbriae in Klebsiella pneumoniae CG43. Microbiology 161, 2395-2409.

(44) Huang, H., Mackel, B. J., and Grove, A. (2013) Streptomyces coelicolor encodes a urate-responsive transcriptional regulator with homology to PecS from plant pathogens. J. Bacteriol. 195, 4954-4965.

(45) Vos, S., de Jersey, J., and Martin, J. L. (1997) Crystal structure of Escherichia coli xanthine phosphoribosyltransferase. Biochemistry 36, 4125-4134.

(46) Leimkuhler, S., Stockert, A. L., Igarashi, K., Nishino, T., and Hille, R. (2004) The role of active site glutamate residues in catalysis of Rhodobacter capsulatus xanthine dehydrogenase. J. Biol. Chem. 279, 40437-40444.

(47) Christiansen, L. C., Schou, S., Nygaard, P., and Saxild, H. H. (1997) Xanthine metabolism in Bacillus subtilis: characterization of the $x p t-p b u X$ operon and evidence for purine- and nitrogen-controlled expression of genes involved in xanthine salvage and catabolism. J. Bacteriol. 179, 2540-2550.

(48) Neumann, M., Schulte, M., Junemann, N., Stocklein, W., and Leimkuhler, S. (2006) Rhodobacter capsulatus XdhC is involved in molybdenum cofactor binding and insertion into xanthine dehydrogenase. J. Biol. Chem. 281, 15701-15708.

(49) Taylor, C. M., Beresford, M., Epton, H. A., Sigee, D. C., Shama, G., Andrew, P. W., and Roberts, I. S. (2002) Listeria monocytogenes relA and $h p t$ mutants are impaired in surface-attached growth and virulence. J. Bacteriol. 184, 621-628.

(50) Eastgate, J. A., Thompson, L., Milner, J., Cooper, R. M., Pollitt, C. E., and Roberts, I. S. (1997) Identification of a nonpathogenic Erwinia amylovora guaB mutant. Plant Pathol. 46, 594-599.

(51) Kriel, A., Bittner, A. N., Kim, S. H., Liu, K., Tehranchi, A. K., Zou, W. Y., Rendon, S., Chen, R., Tu, B. P., and Wang, J. D. (2012) Direct regulation of GTP homeostasis by (p)ppGpp: a critical component of viability and stress resistance. Mol. Cell 48, 231-241.

(52) Cashel, M. (1975) Regulation of bacterial ppGpp and pppGpp. Annu. Rev. Microbiol. 29, 301-318.

(53) Svitil, A. L., Cashel, M., and Zyskind, J. W. (1993) Guanosine tetraphosphate inhibits protein synthesis in vivo. A possible protective mechanism for starvation stress in Escherichia coli. J. Biol. Chem. 268, 2307-2311.

(54) Bennett, B. D., Kimball, E. H., Gao, M., Osterhout, R., Van Dien, S. J., and Rabinowitz, J. D. (2009) Absolute metabolite concentrations and implied enzyme active site occupancy in Escherichia coli. Nat. Chem. Biol. 5, 593-599.

(55) Riccillo, P. M., Collavino, M. M., Grasso, D. H., England, R., de Bruijn, F. J., and Aguilar, O. M. (2000) A guaB mutant strain of Rhizobium tropici CIAT899 pleiotropically defective in thermal tolerance and symbiosis. Mol. Plant-Microbe Interact. 13, 1228-1236.

(56) Romling, U., Galperin, M. Y., and Gomelsky, M. (2013) Cyclic di-GMP: the first 25 years of a universal bacterial second messenger. Microbiol Mol. Biol. Rev. 77, 1-52.

(57) Abarca-Grau, A. M., Penyalver, R., Lopez, M. M., and MarcoNoales, E. (2011) Pathogenic and non-pathogenic Agrobacterium tumefaciens, A-rhizogenes and A-vitis strains form biofilms on abiotic as well as on root surfaces. Plant Pathol. 60, 416-425.

(58) Xu, J., Kim, J., Koestler, B. J., Choi, J. H., Waters, C. M., and Fuqua, C. (2013) Genetic analysis of Agrobacterium tumefaciens unipolar polysaccharide production reveals complex integrated control of the motile-to-sessile switch. Mol. Microbiol. 89, 929-948. 